OPEN ACCESS

Edited by:

Frederic Antonio Carvalho, INSERM U1107 Douleur et Biophysique Neurosensorielle (Neuro-Dol), France

Reviewed by:

Parisa Gazerani,

Oslo Metropolitan University, Norway Saartjie Roux,

Nelson Mandela University,

South Africa

Peter Nagy,

Cornell University, United States

Ivan Bonet,

University of California, San Francisco,

United States

*Correspondence:

Hui Xu

huixu@tjh.tjmu.edu.cn

Specialty section:

This article was submitted to Microbiome in Health and Disease,

a section of the journal

Frontiers in Cellular and Infection Microbiology

Received: 17 August 2021 Accepted: 29 September 2021

Published: 14 October 2021

Citation:

Xu X, Chen R, Zhan G, Wang D, Tan X and $X U H$ (2021) Enterochromaffin

Cells: Sentinels to Gut

Microbiota in Hyperalgesia?

Front. Cell. Infect. Microbiol. 11:760076.

doi: 10.3389/fcimb.2021.760076

\section{Enterochromaffin Cells: Sentinels to Gut Microbiota in Hyperalgesia?}

\author{
Xiaolin Xu ${ }^{1}$, Rongmin Chen ${ }^{2}$, Gaofeng Zhan ${ }^{1}$, Danning Wang ${ }^{1}, X_{i} \operatorname{Tan}^{1}$ and Hui $X u^{1 *}$ \\ ${ }_{1}^{1}$ Department of Anesthesiology, Tongji Hospital, Tongji Medical College, Huazhong University of Science and Technology, \\ Wuhan, China, ${ }^{2}$ Department of Anesthesiology, Huashan Hospital, Fudan University, Shanghai, China
}

In recent years, increasing studies have been conducted on the mechanism of gut microbiota in neuropsychiatric diseases and non-neuropsychiatric diseases. The academic community has also recognized the existence of the microbiota-gut-brain axis. Chronic pain has always been an urgent difficulty for human beings, which often causes anxiety, depression, and other mental symptoms, seriously affecting people's quality of life. Hyperalgesia is one of the main adverse reactions of chronic pain. The mechanism of gut microbiota in hyperalgesia has been extensively studied, providing a new target for pain treatment. Enterochromaffin cells, as the chief sentinel for sensing gut microbiota and its metabolites, can play an important role in the interaction between the gut microbiota and hyperalgesia through paracrine or neural pathways. Therefore, this systematic review describes the role of gut microbiota in the pathological mechanism of hyperalgesia, learns about the role of enterochromaffin cell receptors and secretions in hyperalgesia, and provides a new strategy for pain treatment by targeting enterochromaffin cells through restoring disturbed gut microbiota or supplementing probiotics.

Keywords: enterochromaffin cells, gut microbiota, hyperalgesia, chronic pain, microbiota-gut-brain axis

\section{INTRODUCTION}

Hyperalgesia refers to a decreased pain threshold and an increased response to harmful stimuli, which seriously affects patients' health and quality of life (Nugraha et al., 2019). The central mechanisms of hyperalgesia mainly include glutamate/NMDA (N-methyl-D-aspartic acid) receptor-mediated sensitization, de-inhibition of inhibitory interneurons, and activation of microglia (Basbaum et al., 2009). Peripheral mechanisms include tissue damage and persistent inflammation (Treede et al., 1992). At present, many studies have proved that gut microbiota is involved in the peripheral regulation mechanism of chronic pain, and it is not only confined to visceral pain but also hyperalgesia induced by neuropathic and metabolic diseases (Pellegrini et al., 2018; Yang et al., 2019).

\footnotetext{
Abbreviations: ACC, anterior cingulate cortex; ATP, adenosine triphosphate; BBB, blood-brain barrier; $\mathrm{CB}$, cannabinoid receptor; ECs, enterochromaffin cells; ENS, enteric nervous system; EPSs, exopolysaccharides; FFAR, free fatty acid receptor; GF, germ-free; GPR, G-protein coupled receptor; IBS, irritable bowel syndrome; IL, interleukin; LPS, lipopolysaccharide; Olfr, olfactory receptor; PAMPs, pathogen-associated molecular patterns; SCFAs, short-chain fatty acids; ssRNA, single-stranded RNA; TLR, Toll-like receptors; TRP, transient receptor potentials.
} 
Diverse and stable gut microbiota is vital to the health of the host. The gut microbiota begins to establish soon after the host is born and is continuously affected by external factors, such as antibiotics, diet, stress, etc. The gut microbiota is a dynamic ecosystem that maintains a bidirectional connection with the host through the microbe-gut-organ axis and actively responds to various physiological and pathological conditions. Among them, studies on the mechanism of the microbe-gut-brain axis in neuropsychiatric diseases, including chronic pain and cognition, have attracted the most attention (Pellegrini et al., 2018; Zhan et al., 2018). Gut microbiota can affect the occurrence of visceral pain, inflammatory pain, neuropathic pain, headache, and opioid tolerance through peripheral and central mechanisms (Guo et al., 2019). Their regulatory role in chronic pain has opened up a new idea for pain treatment by restoring healthy gut microbiota (Xu et al., 2021).

The intestinal epithelium is composed of epithelial absorption cells, goblet cells, paneth cells, and enteroendocrine cells. Enterochromaffin cells (ECs) are the most abundant subtype of intestinal enteroendocrine cells in the colon, which can be directly contacted by gut microbiota on the side of the intestinal lumen and interact with the afferent and efferent nerve endings located in the lamina propria by synaptic connection. Although its accounts for less than $1 \%$ of intestinal epithelial cells, it can produce and release $90 \%$ of the serotonin in the body, which is essential for intestinal motility, platelet function, immune response, and bone development (Karsenty and Yadav, 2011; Matthes and Bader, 2018). In addition, ECs are electroexcitatory, similar to other primary sensory cells, expressing functional voltage-gated $\mathrm{Na}^{+}$and $\mathrm{Ca}^{2+}$ channels (Bellono et al., 2017). These important characteristics enable ECs to act as bidirectional information transmitters among the intestinal lumen, intestinal epithelial cells, and specific primary afferent nerve fibers. In brief, ECs are considered the fundamental cells of microbiota-gut-brain interaction in cognition, depression, and chronic pain (Rhee et al., 2009).

\section{GUT MICROBIOTA AND HYPERALGESIA}

Gut microbiota has been recognized as one of the key pain regulators, which can directly or indirectly mediate pain tolerance or sensitization through immune, metabolic, endocrine, and neural signaling pathways. Numerous clinical or pre-clinical studies on chronic pain-related diseases have reported changes in gut microbiota (Braundmeier-Fleming et al., 2016; Clos-Garcia et al., 2019). For example, the diversity of the gut microbiota in patients with fibromyalgia was reduced, and the abundance of Bifidobacterium and Eubacterium genera was significantly reduced (Clos-Garcia et al., 2019). Eggerthella sinensis, Colinsella aerofaciens, Faecalibacterium prasunitzii, Odoribacter splanchnicus, and Lactonifactor longoviformis decreased in patients with bladder pain syndrome (Braundmeier-Fleming et al., 2016). In addition, a large cohort study proved that the abundance of Streptococcus species was linked to the increase in knee joint pain (Boer et al., 2019).
PubMed was searched, and we selected relevant studies before August 1st, 2021. The search keyword string included "hyperalgesia OR chronic pain" AND "gut microbiota OR intestinal flora." To this end, 15 related studies were enrolled. The details of each study are presented in Table $\mathbf{1}$.

In studies related to gut microbiota, the use of antibiotics to construct pseudo-sterile mouse models is a conventional intervention (Yang et al., 2019; Zhang et al., 2019). The common measuring method of behavioral pain response included: mechanical sensitivity by von Frey method, cold sensitivity by cold plantar assay, heat sensitivity by Hargreaves test, or tail-flick test. The imbalance of the gut microbiota caused by antibiotics also impacts the occurrence of pain. However, the effects of antibiotic-induced changes in the gut microbiota on pain have been inconsistent in numerous studies (Shen et al., 2017; Yang et al., 2019). It has been suggested that the lack of gut microbiota may be a protective mechanism in terms of hyperalgesia for the host. Compared with wild mice, inflammatory stimuli, such as carrageenan, lipopolysaccharide (LPS), tumor necrosis factor (TNF)- alpha, interleukin (IL)1beta, and chemokine (C-X-C motif) ligand 1 (CXCL1), cause relatively less noxious reactions in germ-free (GF) mice, while recolonization of the gut microbiota or administration of IL-10 antagonists can reverse this phenomenon in GF mice (Amaral et al., 2008). Similarly, mechanical hyperalgesia in neuropathic pain induced by chemotherapy drugs (paclitaxel, oxaliplatin) and chronic compressive nerve injury pain was reduced in GF mice or antibiotic-treated mice, while recovery of the gut microbiota can disrupt this protective effect and promote chemotherapyinduced mechanical hyperalgesia (Shen et al., 2017; Ramakrishna et al., 2019; Ding et al., 2021). Conversely, some studies have concluded that the interference of antibiotic administration leads to the imbalance of the gut microbiota in mice, which can induce mechanical tenderness and spontaneous pain, accompanied by anxiety, depression-like behaviors, and spatial memory impairment (Aguilera et al., 2015; Yang et al., 2019). Transplanting the gut microbiota from spared nerve injury model rats susceptible to anhedonia into antibiotic treatment rats further aggravated chronic pain and depression-like phenotypes (Yang et al., 2019). In addition, in mice with dysbacteriosis, the cannabinoid receptor (CB) 2 level was upregulated, while the $\mathrm{CB} 1$ and $\mu$ opioid receptors expressions were down-regulated (Aguilera et al., 2013; Aguilera et al., 2015), and large amounts of IL-10 could be produced (Souza et al., 2004), affecting the pain response. Although there are different opinions about the effect of gut microbiota imbalance on chronic pain, which may involve differences in the antibiotic compatibility, detection time, dosage, and even animal models, these experimental results are sufficient to prove that the symbiotic gut microbiota affects the production of hyperalgesia in the host.

Access to effective bacteria or prebiotics is one of the crucial research goals in treating various systemic diseases, and chronic pain is no exception. Lactobacillus paracasei and Bifidobacterium infantis 35624 can normalize pain threshold (Verdú et al., 2006; McKernan et al., 2010). Taking Lactobacillus acidophilus NCFM 
TABLE 1 | Summary of studies investigating links between hyperalgesia and the gut microbiota.

\begin{tabular}{|c|c|c|c|c|}
\hline $\begin{array}{l}\text { Pathology } \\
\text { type }\end{array}$ & $\begin{array}{l}\text { Study Design } \\
\text { (subjects, } \\
\text { intervention) }\end{array}$ & $\begin{array}{l}\text { Bacterie/Bacterial metabolites } \\
\text { (algesia-resilience \& healthy) }\end{array}$ & $\begin{array}{l}\text { Bacterie/Bacterial metabolites } \\
\text { (algesia-sensitivity \& pain) }\end{array}$ & Reference \\
\hline \multicolumn{5}{|c|}{ Human Studies } \\
\hline Back Pain & $\begin{array}{l}36 \text { overweight or } \\
\text { obese patients }\end{array}$ & Dialister, Lactobacillus $\uparrow$ & genera Adlercreutzia, Roseburia, Uncl. Christensenellaceae $\uparrow$ & $\begin{array}{l}\text { (Dekker } \\
\text { Nitert et al., } \\
\text { 2020) }\end{array}$ \\
\hline CWP & $\begin{array}{l}\text { female } 113 \text { CWP } \\
\text { patients and } \\
1623 \text { controls }\end{array}$ & / & $\begin{array}{l}\text { family Lachnospiraceae, family Ruminococcaceae } \downarrow \text {; family } \\
\text { Lachnospiraceae } \uparrow\end{array}$ & $\begin{array}{l}\text { (Freidin et al., } \\
\text { 2021) }\end{array}$ \\
\hline Fibromyalgia & $\begin{array}{l}105 \text { fibromyalgia } \\
\text { patients and } 54 \\
\text { healthy individuals }\end{array}$ & / & 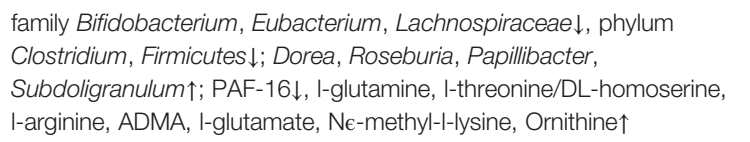 & $\begin{array}{l}\text { (Clos-Garcia } \\
\text { et al., 2019) }\end{array}$ \\
\hline IBS & $\begin{array}{l}253 \text { IBS patients } \\
\text { and } 186 \text { controls }\end{array}$ & $\begin{array}{l}\text { Ruminococcaceae UCG-005, Holdemanella, } \\
\text { Coprococcus 2, Eubacterium } \\
\text { coprostanoligenes group } \uparrow\end{array}$ & $\begin{array}{l}\text { Lachnoclostridium, Dorea, Erysipelatoclostridium, Prevotella 9, } \\
\text { Clostridium sensu stricto } 1 \uparrow\end{array}$ & $\begin{array}{l}\text { (Liu et al., } \\
\text { 2021b) }\end{array}$ \\
\hline IBS & $\begin{array}{l}15 \text { IBS patients } \\
\text { and } 15 \text { healthy } \\
\text { controls }\end{array}$ & / & Lachnospira, Clostridium $\uparrow ;$ L-methionine and homocysteine $\uparrow$ & $\begin{array}{l}\text { (Zhu et al., } \\
\text { 2019) }\end{array}$ \\
\hline IBS & $\begin{array}{l}22 \text { IBS children } \\
\text { and } 22 \text { healthy } \\
\text { children }\end{array}$ & $\begin{array}{l}\text { genus Eubacterium, species Bacteroides } \\
\text { vulgatus } \uparrow\end{array}$ & $\begin{array}{l}\text { phylum Proteobacteria, class Gammaproteobacteria, genera Dorea, } \\
\text { genera Haemophilus, Species H. parainfluenzae and a novel } \\
\text { Ruminococcus-like organism } \uparrow\end{array}$ & $\begin{array}{l}\text { (Saulnier } \\
\text { et al., 2011) }\end{array}$ \\
\hline IC & $\begin{array}{l}\text { female } 17 \\
\text { patients and } 17 \\
\text { controls }\end{array}$ & / & $\begin{array}{l}\text { Eggerthella sinensis, Colinsella aerofaciens, Faecalibacterium } \\
\text { prasunitzii, Odoribacter splanchnicus and Lactonifactor longoviformis } \downarrow\end{array}$ & $\begin{array}{l}\text { (Braundmeier- } \\
\text { Fleming et al., } \\
\text { 2016) }\end{array}$ \\
\hline Joint pain & $\begin{array}{l}124 \text { patients and } \\
817 \text { controls }\end{array}$ & / & Streptococcus $\downarrow$ & $\begin{array}{l}\text { (Boer et al., } \\
\text { 2019) }\end{array}$ \\
\hline \multicolumn{5}{|c|}{ Animal Studies } \\
\hline $\mathrm{CCl}$ & $\begin{array}{l}\text { 5- to 6-week-old } \\
\text { male SD rats }\end{array}$ & $\begin{array}{l}\text { phylum Proteobacteria, Bacteroidetes, } \\
\text { Cyanobacteria, Actinobacteria, Firmicutes } \uparrow\end{array}$ & $\begin{array}{l}\text { phylum Firmicutes, Actinobacteria, Proteobacteria } \uparrow \text {; genus } \\
\text { Lactobacillus, Helicobacter, Blautia, Christensenella, } \\
\text { Phascolarctobacterium, Streptococcus, Rothia } \uparrow, \text { Escherichia, } \\
\text { Corynebacterium, Ignatzschineria, AF12, Butyricimonas } \downarrow\end{array}$ & $\begin{array}{l}\text { (Chen et al., } \\
\text { 2021a) }\end{array}$ \\
\hline CINP & $\begin{array}{l}8 \text { weeks female } \\
\text { C57BL/6J mice } \\
\text { (oxaliplatin, } \\
\text { hydrogen-rich } \\
\text { water) }\end{array}$ & $\begin{array}{l}\text { phylum Firmicutes, Tenericutes } \uparrow \text {, } \\
\text { Bacteroidetes } \downarrow \text {; family Lachnospiraceae, } \\
\text { Lactobacillaceae, Ruminococcaceae } \uparrow \text {; genus } \\
\text { Faecalibacterium, Lactobacillus, Roseburia } \uparrow\end{array}$ & / & $\begin{array}{l}\text { (Lian et al., } \\
\text { 2021) }\end{array}$ \\
\hline $\begin{array}{l}\text { Neuropathic } \\
\text { pain }\end{array}$ & $\begin{array}{l}\text { 8-12 weeks } \\
\text { female C57BL/6 } \\
\text { mice (SNI) }\end{array}$ & $\begin{array}{l}\text { Oscillospira, Erysipelotrichaceae_unclassified, } \\
\text { Adlercreutzia and Turicibacter } \uparrow\end{array}$ & Staphylococcus, Ruminococcaceae_uncultured and Turicibacter $\uparrow$ & $\begin{array}{l}\text { (Brandon- } \\
\text { Mong et al., } \\
\text { 2020) }\end{array}$ \\
\hline $\begin{array}{l}\text { Tactile } \\
\text { allodynia }\end{array}$ & $\begin{array}{l}3 \text { weeks male } \\
\text { C57BL/6 mice } \\
\text { (low vitamin D } \\
\text { concentration) }\end{array}$ & / & Firmicutes $\uparrow$, Verrucomicrobia, Bacteroidetes $\downarrow$ & $\begin{array}{l}\text { (Guida et al., } \\
\text { 2020) }\end{array}$ \\
\hline TMDs & $\begin{array}{l}8 \text { weeks male } \\
\text { C57BL/6 mice } \\
\text { (CFA) }\end{array}$ & / & Bacteroidetes and Lachnospiraceae $\downarrow$ & $\begin{array}{l}\text { (Ma et al., } \\
\text { 2020) }\end{array}$ \\
\hline $\begin{array}{l}\text { Visceral } \\
\text { hyperalgesia }\end{array}$ & $\begin{array}{l}\text { male Wistar rats } \\
\text { WAS/RS) }\end{array}$ & $\begin{array}{l}\text { Lactobacillus } \uparrow \text {; Clostridiaceae, } \\
\text { Erysipelotrichaceae and } \\
\text { Peptostreptococcaceae } \downarrow \text { (after rifaximin } \\
\text { treatment) }\end{array}$ & / & $\begin{array}{l}\text { (Xu et al., } \\
\text { 2014) }\end{array}$ \\
\hline $\begin{array}{l}\text { Visceral } \\
\text { hyperalgesia }\end{array}$ & $\begin{array}{l}\text { male Wistar rats } \\
\text { WAS/RS) }\end{array}$ & $\begin{array}{l}\text { Lactobacillaceae } \uparrow \text {; segmented filamentous } \\
\text { bacteria } \downarrow \text { (after rifaximin treatment) }\end{array}$ & / & $\begin{array}{l}\text { (Gao et al., } \\
\text { 2014) }\end{array}$ \\
\hline
\end{tabular}

$\uparrow$, indicates increase; $\downarrow$, indicates decrease.

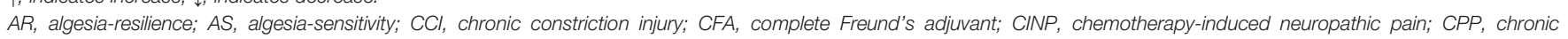

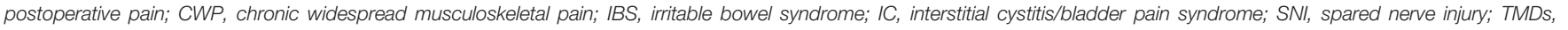
temporomandibular disorders; RS, repeat restraint stress; WAS, chronic water avoidance stress.

strain can induce the expression of $\mu$ opioid receptor and CB2 in intestinal epithelial cells, mediating the analgesic effects similar to morphine (Rousseaux et al., 2007). Intestinal microbial exopolysaccharides (EPSs) have been shown to play an active role in antioxidant, blood pressure and blood glucose regulation, apoptosis, and autophagy of cancer cell lines (Maeda et al., 2004; Di et al., 2017; Tang et al., 2017). Intraperitoneal injection of probiotic strain Lactobacillus paraplantarum BGCG11 (EPS CG11) producing high molecular weight EPSs can significantly reduce the mechanical hyperalgesia of inflammatory pain in 
Wistar rats by decreasing the expression of pro-inflammatory factors IL-1 $\beta$ and inducible nitric oxide synthase (iNOS) (Dinic et al., 2018) (Table 2).

In addition, the imbalance of gut microbiota can lead to structural and metabolic changes in the chronic pain-related brain areas. Anterior cingulate cortex (ACC) volume was decreased, periaqueductal grey volume was increased, and single nerve cells in the ACC also appeared noticeable dendrite changes in pseudo-sterile mice with visceral sensitization (Luczynski et al., 2017). The number of C-Fos immunoreactive neurons in the prefrontal cortex and hippocampus was decreased, while in ACC and insular cortex was increased in mice with dysbacteriosis (Wang et al., 2021a). The amygdala also plays a role in mood disorders, nerve regeneration diseases, and chronic pain. In particular, humans have labeled the laterocapsular division of the central nucleus as "pain-sensitive amygdala." The gut microbiota can affect the morphology, activity, functional connection, and gene expression of the amygdala through the vagus nerve [including the enteric nervous system (ENS)], spinal cord transmission (especially visceral pain), regulation of tryptophan metabolism, and immune regulation (Cowan et al., 2018). The activation of microglia is also associated with the development of chronic pain. The microglia in the brain mainly initiate neuronal apoptosis, clearing dead cells and pruning synapses. However, microglia in antibiotic treatment or GF mice show immature and malformed phenotypes with significantly longer processes and increased numbers of segments, branching, and terminal points. In addition, mice deficient for the short-chain fatty acids (SCFAs) receptor, free fatty acid receptor (FFAR) 2, also showed an immature state of microglia in pseudo-sterile mice, indicating that the presence of gut microbiota is critical for the development, homeostasis, and functional status of microglia in the central nervous system (Erny et al., 2015). A considerable part of the metabolites in mammalian blood is derived from gut microbiota, and changes in the gut microbiota will also affect brain metabolites (Wikoff et al., 2009). Furthermore, GF mice were found to have lower tryptophan (a precursor of 5-HT), tyrosine (a precursor of dopamine and norepinephrine), and glutamine in the brain than mice rich in gut microbiota, in addition to lower energy production and consumption through glycolysis and the tricarboxylic acid cycle (Matsumoto et al., 2013). In GF mice, the blood-brain barrier (BBB) permeability was increased, and the expressions of tight junction proteins such as occludin and claudin-5 in the frontal cortex, striatum, hippocampus were decreased (Braniste et al., 2014). While Clostridium tyrobutyricum or Bacteroides thetaiotaomicron treatment can increase tight junction protein expression and restore $\mathrm{BBB}$ permeability in GF mice, which indicated that the gut microbiota was contributed to maintaining the integrity of the $\mathrm{BBB}$, and the destruction of $\mathrm{BBB}$ caused by gut microbiota imbalance provided a structural basis for harmful intestinal substances to affect the host brain function (Braniste et al., 2014). The above suggested that the gut microbiota is inextricably linked to the host's hyperalgesia (Table 3 ).

\section{GUT MICROBIOTA MEDIUM OR METABOLITES AND HYPERALGESIA}

The role of mediators or metabolites derived from gut microbiota in hyperalgesia is well known. Gut microbiota can release nervous system factors involved in the regulation of gut brain-axis communication, such as 5-HT released by genera Candida, Streptococcus, Escherichia and Enterococcus, dopamine or norepinephrine produced by genera Escherichia, Bacillus and Saccharomyces, acetylcholine generated by genus Lactobacillus, $\gamma$-aminobutyric acid produced by genera Lactobacillus and Bifidobacterium (Holzer and Farzi, 2014). Moreover, gut microbiota-derived mediators can activate Toll-like receptors (TLRs), GABA receptors, and transient receptor potentials (TRP), and so on, participating in the regulation of chronic pain (Santoni et al., 2021).

Pathogen-associated molecular patterns (PAMPs) derived from gut microbiota were significant contributors to peripheral sensitization under chronic pain conditions. PAMPs obtained from gut microbiota included LPS, flagellin, N-formyl peptides, lipoteichoic acid, peptidoglycan, $\beta$-glucan, etc. (Chiu, 2018). They can directly sensitize the primary neurons in the dorsal root ganglia or indirectly by activating immune cells to promote the release of cytokines and chemokines, mediating peripheral sensitization of pain. LPS can send signals to nociceptive dorsal root ganglion neurons in the colon of mice (Ochoa-Cortes et al., 2010). Bacterial flagella can be recognized by the host TLR5 to play a host defenses role (Hayashi et al., 2001) and block the sensitization of dorsal root ganglion A fiber sensory neurons, inhibiting the mechanical hyperalgesia caused by chemotherapy, nerve injury, and diabetic neuropathy (Xu et al., 2015). N-formyl peptide bound to the formyl peptide receptors on the host nociceptive dorsal root ganglia to induce mechanical hyperalgesia (Chiu et al., 2013).

In addition to PAMPs, gut microbiota metabolites are also involved in pain regulation. Microbiota-derived metabolites include SCFAs, bile acids, indole derivatives, vitamins, polyamines, and lipids (Hosseinkhani et al., 2021). Gut microbiota was considered the main producer of SCFAs, providing SCFAs to the host by decomposing fermented starch and dietary fiber. SCFAs included volatile fatty acids fermentation products such as isovaleric acid, isobutyric acid, and butyric acid. Several receptors of SCFAs have been identified as G-protein coupled receptor (GPR) 41/FFAR3, GPR43/FFAR2, GPR109A, and olfactory receptor (Olfr) 78, which mediate leukocyte recruitment, chemokine production, intestinal wall permeability, and BBB permeability changes (Braniste et al., 2014; Ohira et al., 2017). In chronic constriction injury, obesity-induced peripheral neuropathy pain, rheumatoid arthritis pain, changes in SCFAs and butyrate (a histone deacetylase inhibitor) for pain relief were shown. The mechanism involved alleviating the polarization of proinflammatory microglia in the spinal cord and hippocampus (Zhou et al., 2021) and increasing the serotonin metabolite 5hydroxyindole-3-acetic acid, which in turn activated the arylhydrocarbon receptor and inhibited inflammation and pain in a Breg cell-dependent manner (Rosser et al., 2020), changing in the immune cell population of the peripheral nervous system (Bonomo et al., 2020). 
TABLE 2 | Summary of probiotics associated with the underlying mechanisms of pain.

\begin{tabular}{|c|c|c|c|c|c|}
\hline Probiotics & $\begin{array}{l}\text { Pathology } \\
\text { type }\end{array}$ & $\begin{array}{c}\text { Study } \\
\text { Design } \\
\text { (subjects, } \\
\text { intervention) }\end{array}$ & Function & Potential mechanisms related to pain & Reference \\
\hline SLAB51 & CIPN & $\begin{array}{l}\text { male CD1 } \\
\text { mice (PTX) }\end{array}$ & $\begin{array}{l}\text { prevented the } \\
\text { mechanical and cold } \\
\text { hypersensitivity }\end{array}$ & $\begin{array}{l}\text { CB- } 1, \mu, \kappa \text { receptors, PPAR } \gamma \text { protein } \uparrow, \mathrm{p}-\mathrm{Stat} 3, \mathrm{p} \text {-Jak2, p-FAK, } \\
\text { acetylated } \alpha \text {-tubulin in the spinal cord } \downarrow \text {; COX-2, Inos, TNF- } \alpha \text {, IL- } \\
1 \beta, \mathrm{IL}-6 \text { in the serum } \downarrow \text {, IENFs in the paw } \uparrow\end{array}$ & $\begin{array}{l}\text { (Cuozzo } \\
\text { et al., 2021) }\end{array}$ \\
\hline Lactobacillus reuteri & $\begin{array}{l}\text { Colon } \\
\text { obstruction }\end{array}$ & $\begin{array}{l}\text { 8-10 weeks } \\
\text { male } \\
\text { Sprague- } \\
\text { Dawley rats }\end{array}$ & $\begin{array}{l}\text { decreased sensory } \\
\text { neuron } \\
\text { hyperexcitability and } \\
\text { referred hyperalgesia } \\
\text { in colon obstruction }\end{array}$ & Restored $\mu, \delta, \kappa$ receptors (MOR-1, DOR- 1 , KOR-1, respectively) & $\begin{array}{l}\text { (Hegde } \\
\text { et al., 2020) }\end{array}$ \\
\hline $\begin{array}{l}\text { Lactobacillus reuteri DSM } \\
17938\end{array}$ & $\begin{array}{l}\text { Functional } \\
\text { abdominal } \\
\text { pain }\end{array}$ & children & $\begin{array}{l}\text { reduced the intensity } \\
\text { of pain and increased } \\
\text { the pain-free days }\end{array}$ & None & $\begin{array}{l}\text { (Romano } \\
\text { et al., 2014; } \\
\text { Weizman } \\
\text { et al., 2016; } \\
\text { Jadrešin } \\
\text { et al., 2017; } \\
\text { Jadrešin } \\
\text { et al., 2020) }\end{array}$ \\
\hline $\begin{array}{l}\text { Lactobacillus acidophilus } \\
\text { NCFM }\end{array}$ & $\begin{array}{l}\text { Functional } \\
\text { abdominal } \\
\text { pain }\end{array}$ & $\begin{array}{l}20 \text { caucasian } \\
\text { women with } \\
\text { mild to } \\
\text { moderate } \\
\text { abdominal } \\
\text { pain }\end{array}$ & $\begin{array}{l}\text { reduced visceral } \\
\text { sensitivity }\end{array}$ & modulates mu-opioid receptor expression and activity & $\begin{array}{l}\text { (Ringel- } \\
\text { Kulka et al., } \\
\text { 2014) }\end{array}$ \\
\hline $\begin{array}{l}\text { Bacillus coagulans GBI-30, } \\
6086\end{array}$ & IBS & $\begin{array}{l}44 \text { IBS } \\
\text { patients } \\
\text { (probiotics: } \\
\text { 22, placebo: } \\
\text { 22) }\end{array}$ & $\begin{array}{l}\text { relieved of abdominal } \\
\text { pain and bloating }\end{array}$ & None & (Hun, 2009) \\
\hline $\begin{array}{l}\text { Lactobacillus plantarum } \\
\text { PS128 }\end{array}$ & IBS & $\begin{array}{l}8 \text { weeks male } \\
\text { Sprague- } \\
\text { Dawley rats }\end{array}$ & $\begin{array}{l}\text { reduced visceral } \\
\text { hypersensitivity }\end{array}$ & $\begin{array}{l}\text { substance } \mathrm{P}, \mathrm{CGRP}, \mathrm{BDNF}, \mathrm{NGF} \text { in the dorsal root ganglion } \uparrow \text { but } \\
\text { in the spinal cord } \downarrow \text {; corticosterone in serum and mineralocorticoid } \\
\text { receptors in the amygdala } \downarrow\end{array}$ & $\begin{array}{l}\text { (Liu et al., } \\
\text { 2020) }\end{array}$ \\
\hline $\begin{array}{l}\text { Saccharomyces cerevisiae } \\
\text { I-3856 }\end{array}$ & IBS & $\begin{array}{l}379 \text { IBS } \\
\text { patients }\end{array}$ & $\begin{array}{l}\text { does not improve } \\
\text { intestinal pain and } \\
\text { discomfort }\end{array}$ & None & $\begin{array}{l}\text { (Spiller et al., } \\
\text { 2016) }\end{array}$ \\
\hline $\begin{array}{l}\text { Bifidobacterium bifidum } \\
\text { MIMBb75 }\end{array}$ & IBS & $\begin{array}{l}122 \text { IBS } \\
\text { patients } \\
\text { (placebo: 62, } \\
\text { MIMBb75: 60) }\end{array}$ & $\begin{array}{l}\text { improved pain/ } \\
\text { discomfort, distension/ } \\
\text { bloating, urgency and } \\
\text { digestive disorder }\end{array}$ & None & $\begin{array}{l}\text { (Guglielmetti } \\
\text { et al., 2011) }\end{array}$ \\
\hline $\begin{array}{l}\text { Bifidobacterium longum, B. } \\
\text { bifidum, B. lactis, } \\
\text { Lactobacillus acidophilus, } \\
\text { L. rhamnosus, } \\
\text { Streptococcus } \\
\text { thermophilus }\end{array}$ & IBS & $\begin{array}{l}49 \text { IBS } \\
\text { patients } \\
\text { (probiotics: } \\
\text { 25, placebo: } \\
\text { 24) }\end{array}$ & $\begin{array}{l}\text { improvement in } \\
\text { abdominal pain/ } \\
\text { discomfort and } \\
\text { bloating }\end{array}$ & $\begin{array}{l}\text { B. lactis, L. rhamnosus, and } S \text {. thermophilus } \uparrow \text { in the probiotics } \\
\text { group after } 4 \text { weeks and that } B \text {. lactis } \uparrow \text { in the placebo group. }\end{array}$ & $\begin{array}{l}\text { (Yoon et al., } \\
\text { 2014) }\end{array}$ \\
\hline $\begin{array}{l}\text { VSL\#3 (a mixture of } 8 \\
\text { probiotic bacteria strains) }\end{array}$ & IBS & $\begin{array}{l}\text { male Wistar } \\
\text { rats (neonatal } \\
\text { maternal } \\
\text { separation) }\end{array}$ & $\begin{array}{l}\text { reversed both } \\
\text { allodynia and } \\
\text { hyperalgesia in } \\
\text { neonatal maternal } \\
\text { separation Rats }\end{array}$ & $\begin{array}{l}\text { VSL\#3 counter-regulated genes (CCL2, NOS3, IL10 and } \\
\text { TNFRSF1B) involved in the inflammatory cascade and genes } \\
\text { (TLRs, NFKB and MAPKs) that encode for factors that regulate } \\
\text { the innate and adaptive immune response, thus inhibiting } \\
\text { inflammatory and nociceptive processes }\end{array}$ & $\begin{array}{l}\text { (Distrutti } \\
\text { et al., 2013) }\end{array}$ \\
\hline Lactobacillus rhamnosus & Osteoarthritis & $\begin{array}{l}6 \text { weeks male } \\
\text { Wistar rats } \\
\text { (MIA) }\end{array}$ & $\begin{array}{l}\text { decreased pain } \\
\text { severity and cartilage } \\
\text { destruction }\end{array}$ & decreased Intestinal damage and inflammation & $\begin{array}{l}\text { (Jhun et al., } \\
\text { 2021) }\end{array}$ \\
\hline Isomalto-oligosaccharides & VHS & $\begin{array}{l}\text { male Wistar } \\
\text { rats (WAS) }\end{array}$ & $\begin{array}{l}\text { increased pain } \\
\text { threshold }\end{array}$ & repaired damage of intestinal epithelial ultrastructure & $\begin{array}{l}\text { (Wang et al., } \\
2017 \text { b) }\end{array}$ \\
\hline Lactobacillus plantarum & VHS & $\begin{array}{l}\text { male } \\
\text { Sprague- } \\
\text { Dawley rats } \\
\text { (colorectal } \\
\text { distensio) }\end{array}$ & $\begin{array}{l}\text { D-alanine depletion of } \\
\text { lipoteichoic acid in } \\
\text { Lactobacillus } \\
\text { plantarum inhibited } \\
\text { visceral pain } \\
\text { perception }\end{array}$ & $\begin{array}{l}\text { decreased the activation-induced release of TNF and IFN-gamma } \\
\text { from mesenteric T cells and the IL-10 concentration in colonic } \\
\text { tissue, while increasing the activation-induced secretion of IL-10 in } \\
\text { splenocytes and mesenteric lymphocytes and the baseline IL-10 } \\
\text { release ofsplenocytes. }\end{array}$ & $\begin{array}{l}\text { (Duncker } \\
\text { et al., 2008) }\end{array}$ \\
\hline
\end{tabular}


TABLE 2 | Continued

\begin{tabular}{|c|c|c|c|c|c|}
\hline Probiotics & $\begin{array}{l}\text { Pathology } \\
\text { type }\end{array}$ & $\begin{array}{c}\text { Study } \\
\text { Design } \\
\text { (subjects, } \\
\text { intervention) }\end{array}$ & Function & Potential mechanisms related to pain & Reference \\
\hline $\begin{array}{l}\text { Lactobacillus paracasei } \\
\text { (NCC2461) }\end{array}$ & VHS & $\begin{array}{l}\text { female NIH } \\
\text { Swiss mice } \\
\text { (bacitracin, } \\
\text { neomycin, } \\
\text { primaricin) }\end{array}$ & $\begin{array}{l}\text { attenuates antibiotic } \\
\text { induced visceral } \\
\text { hypersensitivity }\end{array}$ & normalized visceral sensitivity and substance P immunolabelling & $\begin{array}{l}\text { (Verdú et al., } \\
\text { 2006) }\end{array}$ \\
\hline
\end{tabular}

$\uparrow$, indicates increase; $\downarrow$, indicates decrease.

CIPN, chemotherapy-induced peripheral neuropathy; COX-2, cyclooxygenase-2; FSH, follicle-stimulating hormone; IENFs, intra-epidermal fiber; iNOS, inducible nitric oxide synthase;

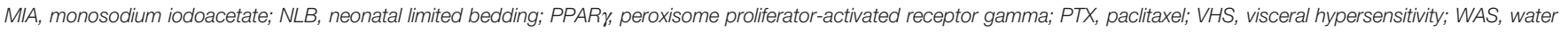
avoidance stress.

TABLE 3 | The studies associated with changes in brain regions and gut microbiota.

$\begin{array}{lll}\text { Study Design (subjects, } & \text { Bacteries } & \text { Changes in brain region (intestinal dysbacteriosis) } \\ \text { intervention) }\end{array}$

intervention)

GF and SPF NMRI mice /

noradrenaline, dopamine, and 5-HT turnover $\uparrow$ in the striatum; NGFI-A mRNA $\downarrow$ in the orbital frontal cortex, striatum, hippocampus (CA1,CA3 region, dentate gyrus), amygdala; BDNF mRNA $\downarrow$ in the hippocampus, amygdala, cingulate cortex in GF mice compared with SPF mice. Synaptophysin and PSD-95 in the striatum $\downarrow$ in SPF and CON mice compared with GF mice.

5 weeks male C57BL/6 mice (bacitracin, neomycin, natamycin, meropenem, vancomycin) male Wistar rats (T2DM; Lactobacillus plantarum, inulin, or synbiotic)

Healthy women (FMPP: 12, controls: 11, no intervention: 13)

Firmicutes, Bacteroidetes $\downarrow$, Proteobacteria $\uparrow$ dominant populations were lactobacillus / tight-junction proteins $\downarrow$ of the brain blood vessels and BBB permeability $\uparrow$ in antibiotic treated mice

Lactobacillus plantarum led to a significant decrease in TLR-2 as well as GDNF and GFAP only in the amygdala

(Diaz Heijtz et al., 2011)

(Sun et al., 2021)

(Hosseinifard et al., 2019)

FMPP reduces the reactivity of a widely distributed network of brain regions (primary interoceptive and somatosensory regions, and a cluster in the midbrain region centered on the periaqueductal gray, the prefrontal cortex, precuneus, basal ganglia, and the parahippocampal gyrus) to an emotional attention task.

103 miRNAs (61 downregulated, 42 upregulated) changed in the amygdala, and 31 miRNAs (21 downregulated, 10 upregulated) altered in the PFC in GF animals

(Tillisch et al., 2013)

Swiss Webster (GF and CON mice); / Adult male Sprague Dawley rats (ampicillin, vancomycin, ciprofloxacin HCL, imipenem, metronidazole)

BALB/c mice (SPF and GF mice) /

12 weeks C57BL/6J mice (SPF and / GF mice)

Swiss Webster (GF and CC mice) /

6 weeks male C57BL/6J mice (ampicillin, streptomycin, clindamycin)

GF mice (E. coli JM83, complex microbiota, or no microbiota)
I-aspartic acid in striatum, cerebral cortex and hippocampus, and I-arginine, I-alanine and Ivaline in striatum $\uparrow$ in SPF mice than in GF mice microbiota dependent-hypomyelination of several gray matter structures (neocortex, HIP, brainstem) and major white matter tracts (the corpus callosum, anterior commissure, internal capsule) specifically in GF mice using MPF imaging.

the volumes of ACC $\downarrow$ and periaqueductal grey $\uparrow$, dendritic changes in the ACC were evident in GFmice.

Bifidobacterium, Fos immunoreactive (ir) neurons in mPFC and $\mathrm{HIP} \downarrow$, in ACC and IC $\uparrow$ in antibiotic treated mice Escherichia Coli, Lactobacillus $\downarrow$ /
Fos in

displayed disorganization of gene co-expression networks in HIP, amygdala, mPFC in E. coli JM83 treated mice
(Kawase et al., 2017)

(Lu et al., 2018)

(Luczynski

et al., 2017)

(Wang et al., 2021b)

(Philip et al., 2021)

$\uparrow$, indicates increase; $\downarrow$, indicates decrease.

ACC, anterior cingulate cortex; BBB, blood-brain barrier; CC, conventionally colonized; FMPP, fermented milk product with probiotic, containing Bifidobacterium animalis subsp Lactis, Streptococcus thermophiles, Lactobacillus bulgaricus, and Lactococcus lactis subsp Lactis; GDNF, glial cell-derived neurotrophic factor; GFAP, glial fibrillary acidic protein; GF, germ-free; HIP, hippocampus; IC, insular cortex; PFC, prefrontal cortex; SPF, specific pathogen -free; T2DM, type 2 diabetes mellitus.

\section{THE INTERACTION OF HYPERALGESIA- RELATED RECEPTORS IN ECs WITH INTESTINAL FLORA AND ITS METABOLITES}

ECs, as intestinal epithelial chemoreceptors, can detect gastrointestinal symbiotic bacteria, infectious microorganisms, food intake, endogenous regulatory substances, etc. It has been found that allyl isothiocyanate, isovalerate, isobutyrate, butyrate, catecholamines, and son on can specifically and continuously activate ECs, trigger $\mathrm{Ca}^{2+}$ transients, and participate in a variety of pathophysiological states (Bellono et al., 2017). From the perspective of chronic pain-related receptors of ECs, the possible hyperalgesia targets of ECs interacting with gut microbiota are discussed below. 


\section{TRP Family}

The TRP family is a kind of non-selective transmembrane cation channels superfamily, which can be divided into seven subfamilies according to different amino acid sequences: TRPC (canonical), TRPV (vanilloid), TRPM (melastatin), TRPP (polycystin), TRPML (mucolipin), TRPA (ankyrin) and TRPN (NOMPC like, or no mechanoreceptor potential C). They maintain the transmembrane transport of cell $\mathrm{Na}^{+}, \mathrm{Ca}^{2+}$ and $\mathrm{Mg}^{2+}$, and intracellular organelle homeostasis, participating in various pathophysiological processes such as neurodegenerative diseases and gastrointestinal peristalsis (Nilius and Owsianik, 2011; Blackshaw, 2014; Nilius and Szallasi, 2014). Among them, at least TRPV1-4, TRPM8 and TRPA1 are expressed in nociceptive sensory neurons, which transfer thermal, chemical, and mechanical stimulation signals, playing an important role in the occurrence and development of pathological pain perception (Dai, 2016). TRPV1 (Deng et al., 2021), TRPV5 and 6 (Hua et al., 2019), TRPM7 (Lv et al., 2020) and 8 (Wen et al., 2020), TRPA1 (Pagano et al., 2019), TRPP1 (Beer et al., 2019) have all been found to have some associations with the gut microbiota, but so far only the TRPA1 receptor has been studied in ECs (Nozawa et al., 2009).

TRPA1 is a chemoreceptor widely expressed in humans and animals, including dorsal root ganglia, bladder, gastrointestinal tract, skin, respiratory tract, blood vessels, etc. It helps to sense pain, temperature $\left(<17^{\circ} \mathrm{C}\right)$, mechanical stimulation, and chemical stimulants. It has become a target for the development of analgesic and anti-inflammatory drugs. Its functional mutations were considered one of the pathogeneses of familial paroxysmal pain syndrome (Kremeyer et al., 2010). TRPA1 receptor is activated by allyl isothiocyanate, cinnamaldehyde, organic sulfur compounds in garlic and onions, and smoke bombs (Bautista et al., 2006). In the gastrointestinal tract, the TRPA1 receptor is mainly expressed in the visceral afferent nerves, which can sense exogenous dietary stimuli such as mustard and garlic and endogenous inflammatory factors such as prostaglandins and other lipidderived metabolites (Logashina et al., 2019). As the main detector of luminal irritants on the intestinal mucosa, the TRPA1 receptor is necessary for the normal mechanical and chemical sensory functions of specific subsets of the vagus, viscera, and pelvic afferent nerve (Brierley et al., 2009). It has been demonstrated that TRPA1 is a molecular target of LPS, a toxic substance produced by bacterial lysis, that directly acts on nociceptive sensory neurons. This finding provides new insight into the mechanism of hyperalgesia during bacterial infection (Meseguer et al., 2014). IL-33 can be expressed and released by damaged tissues or necrotic barrier cells to participate in intestinal infections and type II immune responses. The IL-33/ST2 signaling pathway is an important signal to activate the dorsal horn ganglion and induce pain and itch (Han et al., 2013). IL-13/ ST2 signaling pathway can mediate the rapid release of 5-HT from ECs dependent on the TRPA1 receptor and then cause the corresponding symptoms of 5-HT dysregulation (Chen et al., 2021b). In addition, cinnamaldehyde can also stimulate the QGP-1 cells of the human ECs model to release 5-HT in a dose-dependent manner by activating TRPA1 (Lieder et al., 2020).

\section{Piezo1/2}

Since piezo1/2 was identified in mammalian cells in 2010 (Coste et al., 2010), the research focus of piezo1/2 has expanded from its structure to activation mechanism and its role in physiology and pathology (Kim et al., 2012; Guo et al., 2021). Piezo1/2 is a new type of mechanical ion channel that can be expressed in neurons, endothelial cells, red blood cells, etc. It acts as a multi-functional mechanical sensor in the bladder, colon, kidney, lung, and skin. Mechanical stimulus signals, such as tension and pulsation, are converted into electrochemical signals, which play an important role in blood vessel development, bone formation, and somatosensory conduction (Ranade et al., 2014a; Ranade et al., 2014b; Syeda et al., 2016; Jiang et al., 2021). Piezo1 is predominantly expressed in non-sensory tissues, while piezo2 is mainly expressed in sensory tissues. Some early studies focused on the role of piezo1/2 in the trigeminal nervous system (Fernández-Trillo et al., 2020; Dolgorukova et al., 2021). For example, IL- 6 can cause trigeminal neuralgia by activating piezo2 (Liu et al., 2021a). In addition, activating piezo1 receptor on trigeminal nerve nociceptive fibers can trigger the release of calcitonin gene -related peptide, a key mediator of migraine (Mikhailov et al., 2019). The mechanisms of epac1-piezo2 axis in bone cancer pain, inflammatory pain, and mechanical allodynia of neuropathic pain have also been investigated (Eijkelkamp et al., 2013; Singhmar et al., 2016; Ni et al., 2021). Piezo1/2 also exists in intestinal epithelial cells, and the expression level in the colon is higher than that in the small intestine. Piezo2 in the colon is significantly negatively correlated with the visceral sensitivity of irritable bowel syndrome (IBS) (Bai et al., 2017). Selectively and high expression of piezo 2 in human and mouse ECs can sense mechanical stimulation and induce the release of 5-HT (Wang et al., 2017a). More interestingly, piezol can induce ECs to produce 5-HT by sensing the single-stranded RNA (ssRNA) of the gut microbiota (rather than protein and DNA). ssRNA-stimulated Piezol induced a significant calcium response to release 5-HT in a MyD88/TRIF-independent and canonical Wnt signaling-independent manner, promoting intestinal motility and reducing bone mass, etc., independently of the stimulation of mechanical intestinal peristalsis (Sugisawa et al., 2020). Although the mechanism by which ssRNA of the gut microbiota activates piezo1/2 has still not been fully explained, the groundbreaking discovery of the interaction between the gut microbiota and piezo1/2 in ECs could be a theoretical cornerstone for treating hyperalgesia with gut microbiota.

\section{Olfactory Receptor (OIfr)}

Although Olfrs are a type of GPR mainly responsible for the volatile odor signals transduction in olfactory neurons, they can be ectopically expressed in non-olfactory tissues, such as the heart, skin, lungs, and intestinal epithelium, etc., with both olfactory and non-olfactory functions (Braun et al., 2007; Chen et al., 2018). Olfr plays an important role in many physiological and pathological processes such as sensory perception, behavior 
and emotion regulation, immune system activity and inflammation regulation, tumor growth, and metastasis (Meijerink, 2021). Although there were few studies on its mechanism of action in hyperalgesia, the current research status suggests that it is closely related to hyperalgesia in certain diseases (Lee et al., 2019). The genome-wide association study of blood samples from breast cancer patients showed that the occurrence of pain after adjuvant radiotherapy was significantly associated with the activity of Olfr genes (OR52N1, OR4C12, OR4A47) (Lee et al., 2019). Wholegenome analysis of whole blood samples from patients with head and neck tumors showed that Olfr genes (OR13G1, OR6F1, OR14A2) were susceptibility genes for pretreatment pain (ReyesGibby et al., 2016). In addition, R-carvone-responsive Olfr OR1A1 has been used in a pre-clinical study to design cells controlled by peppermint aromatherapy to treat chronic pain (Wang et al., 2018). In recent years, Olfr78/OR51E2 and Olfr558/ OR51E1, members of the olfactory GPR subfamily, have been identified as sensors for SCFAs and/or branched-chain fatty acids in the intestine. Olfr78, the SCFAs receptor on enteroendocrine cells, shows a specific affinity for acetic acid and propionic acid. It can promote the secretion of anorexigenic gut hormone peptide YY in mice intestinal enteroendocrine cells, regulate appetite, and maintain energy homeostasis (Nishida et al., 2021). Propionic acid can regulate blood pressure in mice by regulating renin release and vascular tension, proving a subtle relationship between gut microbial metabolites and Olfr78 on vascular smooth muscle cells in blood pressure control (Pluznick et al., 2013; Pluznick, 2014). In addition, acetic acid and propionic acid can also act on the Olfr OR51E2 (human-derived Olfr78) on airway smooth muscle cells to slow down the remodeling of cytoskeleton and the proliferation of airway smooth muscle cells, becoming specific receptors targeting the intestine-lung axis to treat asthma (Aisenberg et al., 2016). These suggest that certain specific connections between the gut microbiota with its metabolites and Olfrs play a role in the physiological and pathological processes. In addition, the intestinal odors can stimulate the release of 5-HT through the Olfrs localized at the apical side of ECs (Braun et al., 2007) to participate in the occurrence of gastrointestinal diseases such as IBS. Recently, it has been further discovered that isovaleric acid can act as a ligand for Olfr558, which can activate Goolf/s-adenylyl cyclase signaling in ECs, induce 5$\mathrm{HT}_{3}$ secretion involved in the occurrence of visceral sensitivity (Bellono et al., 2017). Therefore, the excavation of the mechanism of Olfrs on ECs will be more conducive to understanding the relationship between the gut microbiota and various pain-related diseases.

\section{$\alpha 2$ Aadrenoreceptor}

Research on the role of gut microbiota and its metabolites acting through adrenergic receptors is mainly manifested in lipid metabolism and cardiovascular aspects, such as promoting platelet thrombosis (Huynh, 2020). Changes in the gut microbiota will also affect the host catecholamine hormone levels. It was found that the level of free catecholamines in the intestine of pseudo-sterile mice was lower than that of specific pathogen-free mice, and most of the catecholamines in the intestines of pseudo-sterile mice were non-biologically active conjugated forms. In contrast, catecholamines in the intestines of specific pathogen-free mice are biologically active free form (Asano et al., 2012). The levels of catecholamines in the intestines, especially norepinephrine, fluctuate with infection, inflammation, or sympathetic tone. Norepinephrine is an effective bacterial stimulator that can upregulate the proliferation, toxicity, and adhesion of bacteria. However, longterm infection and injury can cause chronic visceral sensitization. Norepinephrine can increase the growth rate, vitality, and invasion of Campylobacter jejuni, destroying the tight junctions of the intestinal epithelium (Cogan et al., 2007). Norepinephrine, exudated from the noradrenergic nerve terminal or the capillaries in the intestinal wall, can activate the adrenergic-like QseC receptor on the surface of the bacteria in the intestinal lumen, altering the virulence of the microbiota via autoinducer 3mediated signaling pathways. Simultaneously, the autoinducer three released by gut microbiota into the intestinal lumen can activate intestinal epithelium's adrenergic receptors, reduce intestinal epithelial cell fluid secretion, and impair the host's ability to expel pathogens (Rhee et al., 2009). Among the adrenergic receptors, only $\alpha 2 \mathrm{~A}$ adrenergic receptors are expressed in ECs, located on the basolateral side, and receiving sympathetic excitatory stimulation. Adro2A-TRPC4 mediates the catecholamine sensitivity of ECs through a Goi-dependent signaling cascade (Bellono et al., 2017). The destruction of the gut microbiota induced by antibiotic vancomycin in the neonatal period resulted in visceral allergy in adult male rats, accompanied by decreased mRNA expression of $\alpha$-2A adrenergic receptor and TRPV1 receptor in the lumbosacral spinal cord (O'Mahony et al., 2014), so $\alpha 2 \mathrm{~A}$ adrenergic receptors may act as a chronic pain target for gut microbiota.

\section{SEROTONIN SIGNALING BY ECs}

Part of the 5-HT secreted by ECs can be used as neurotransmitters for synaptic connection with primary afferent nerve fibers. In contrast, the other part can be circulated to other tissues, including the brain, through blood circulation to participate in osteogenesis, learning, memory, emotional regulation, pain tolerance, etc. It is a crucial signal molecule in the bidirectional communication system between the brain and the gut (Crowell and Wessinger, 2007; Gershon, 2013). A variety of intestinal stimulants, such as mechanical stimulation, diet, gastric acid, bacterial metabolites, viruses, and drugs, can trigger ECs to release 5-HT to intestinal mast cells, spinal afferent nerves, and neurons in the ENS, eventually causing afferent nociceptive and mechanical sensitivity terminal receptor sensitivity, resulting in hyperalgesia (Akiba et al., 2017; Wood, 2020). Under normal physiological conditions, the release of 5-HT can stimulate the intestinal epithelium and ENS, maintain the contraction of intestinal smooth muscle, and facilitate the elimination of harmful bacteria in the intestinal lumen. However, the proliferation of ECs and increased availability of 5-HT are involved in the development of visceral sensitization and peripheral mechanical 
hyperalgesia in IBS (Cremon et al., 2011; Qin et al., 2019; Nascimento et al., 2021). For example, stimulating FFAR2 on ECs can enhance the defense function of the duodenal mucosa by increasing $\mathrm{HCO}^{-}$secretion and regulating 5-HT biosynthesis. However, excessive activation of FFAR2, which drives the excessive release of 5 -HT, can cause mucosal damage by reducing mucosal blood flow (Akiba et al., 2017). The presence of serotonin transporter knockouts in female mice can also exhibit visceral sensitization and gastrointestinal motility disorders, such as low pain pressure threshold and increased fecal output, accompanied by the increased relative proportion of ECs and colon 5-HT concentration (Bi et al., 2021). The mechanism by which ECs release 5-HT is also related to adenosine triphosphate (ATP) and its metabolites. ATP and its breakdown products are a purinergic transmitter in the ENS, which can initiate enteric nerve reflex or activate afferent nerve endings to transmit pain to the brain. Through BON cells or EC cells isolated from human intestinal surgery specimens, it is verified that ECs can respond to ATP, uridine triphosphate (UTP) and uridine diphosphate (UDP), mainly by activating P2X3, P2Y4R and PLC/IP3/IP3R/ SERCA $\mathrm{Ca}^{2+}$ signaling pathways, to involve in visceral sensitization and pain production (Xu et al., 2008; Liñán-Rico et al., 2017). In addition, metabolites of norepinephrine and isovalerate activate ECs to release 5-HT (Bellono et al., 2017). And 5-HT can also activate TRPV4 to mediate visceral hypersensitivity through protein kinase $\mathrm{C}$ (PKC), phospholipase Cbeta (PLCbeta), mitogen-activated protein kinase kinase
(MAPKK) and phospholipase A2 (PLA2)-dependent mechanisms (Cenac et al., 2010).

\section{GUT MICROBIOTA-ECs-VAGAL AFFERENT NERVES SIGNALING}

A large number of studies have suggested that the vagus nerve is one of the key pathways in the mechanism of the gut-brain axis (O'Mahony et al., 2011; Xu et al., 2020). The gastrointestinal tract not only contains a huge microbial ecosystem but also includes ENS composed of tens of thousands of sensory afferent neurons. The enteric vagus nerve originates from the neural crest cells of the vagus nerve and is comprised of nerve plexus embedded in the intestinal wall. Due to its autonomy, neurotransmitter diversity, and complex cell structure, ENS enjoys the "second brain" reputation (Fattahi et al., 2016). ENS is connected with the central autonomic neural network of the brain through the parasympathetic nerves and sympathetic nerves. These sympathetic and parasympathetic nerves can regulate ENS through afferent and efferent activities, thereby forming the bidirectional activity of the gut-brain axis. The intestinal vagus nerve regulates the contraction of gastrointestinal smooth muscle and the secretion of glands, innervates the gastrointestinal mucosal mechanical receptors, chemoreceptors, and tension receptors, and transmits sensations to the nucleus tractus solitarius, and then projects to the central nervous system, such as the amygdala, thalamus, and the locus coeruleus, etc. The colonization of the gut microbiota will also affect the

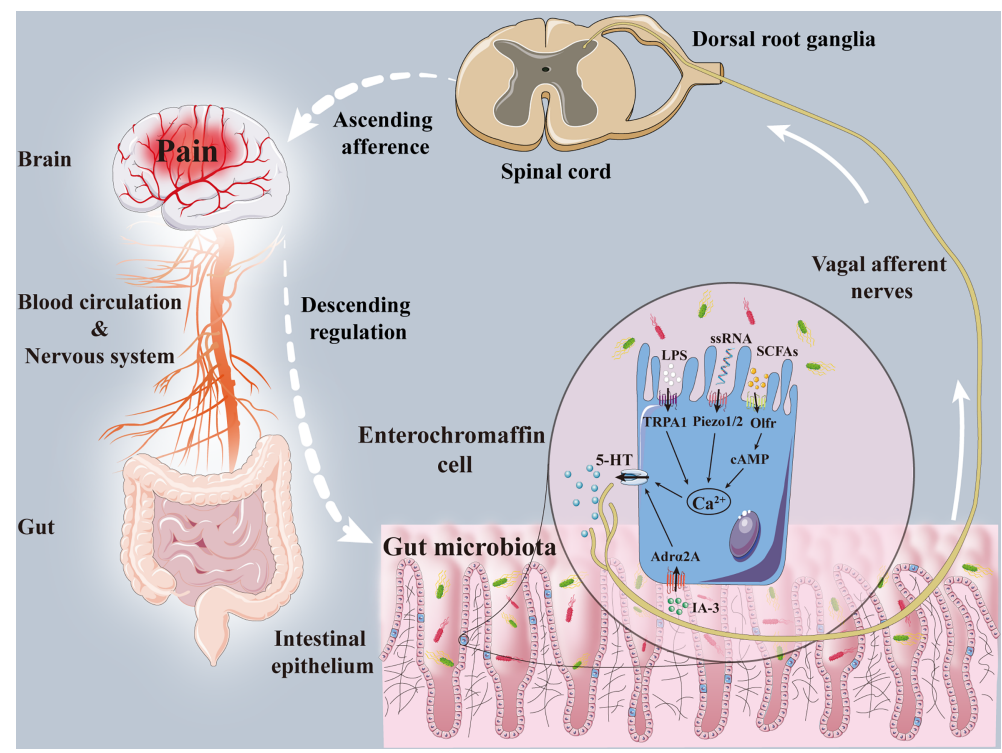

FIGURE 1 | The mechanisms of enterochromaffin cells in the interaction between gut microbiota and pain. Gut microbiota and its metabolites, including IA-3, SSRNA, SCFAs and LPS, acted on enterochromaffin cells receptors (Adro2A, piezo1/2, cAMP, Olfr, TRPA1) to induce the release of 5-HT. Part of 5-HT transferred hyperalgesia signals to dorsal root ganglia and spinal dorsal horn through the vagal afferent nerve. Pain signals are then transmitted to the brain through the spinalthalamic tract and other ascending afferent tracts, and eventually integrated through the cerebral cortex and limbic system. After that, the brain can regulate pain sensation through descending regulation and neuromediators. Adro2A, $\alpha 2 \mathrm{~A}$ adrenoreceptor; cAMP, cyclic adenosine monophosphate; IA-3, autoinducer 3; LPS, lipopolysaccharide; Olfr, olfactory receptor; SCFAs, short-chain fatty acids; ssRNA, single-stranded RNA; TRPA1, transient receptor potential A1; 5-HT, 5-hydroxytryptamine. 
development, excitability, and plasticity of the ENS (Collins et al., 2014; Hyland and Cryan, 2016). The excitability of endogenous primary afferent neurons was reduced, and nitrergic neurons were increased, and calbindin positive neurons and glial cells were decreased in the colon and ileum muscle of GF mice. While the colonization of normal gut microbiota can restore neurons excitability and the number of calbindin positive neurons (McVey Neufeld et al., 2013; Hyland and Cryan, 2016). In addition, colonization of Bacteroides thetaiotaomicron restored the growth of neurites and glial cells and the expression of nitric oxide synthase, substance P, and other neurotransmitters (Aktar et al., 2020). The probiotic Saccharomyces boulardii reduced the calcium-binding protein intermuscular neurons in pig jejunum (Kamm et al., 2004). Pediococcus acidilactici treatment increased galanin and calcitonin gene-related peptide-immunoreactive neurons and glial fibrillary acidic protein-positive enteric glial cells in submucosal ileal ganglion of piglets (di Giancamillo et al., 2010). All the above proved that the gut microbiota can selectively affect the growth and stability of the ENS. Hence, ECs was considered one of those mediators promoting the communication between the gut microbiota and ENS (Bohórquez et al., 2015; Yano et al., 2015). ECs releases 5-HT to regulate the growth, maintenance, and nerve reflex of the intestinal mucosa and ENS by stimulating $5-\mathrm{HT}$ receptors on submucosal primary afferent neurons (Pan and Gershon, 2000; Gross et al., 2012). Clinical data showed that the increased number of ECs was present in the colonic mucosa of IBS patients, and the increased 5-HT released from the mucosa was related to the severity of discomfort such as abdominal pain. Perfusion of colonic mucosal supernatant in IBS patients resulted in significant activation of mesenteric sensory neurons, inhibited by $5-\mathrm{HT}_{3}$ receptor antagonists, indicating that 5-HT released by ECs can affect the ENS in hyperalgesia (Cremon et al., 2011) (Figure 1).

Throughout the gastrointestinal tract, there are other enteroendocrine cells except ECs, there are interactions between these cells and ECs, such as hormone stimulation, and so on (Yu

\section{REFERENCES}

Aguilera, M., Cerdà-Cuéllar, M., and Martínez, V. (2015). Antibiotic-Induced Dysbiosis Alters Host-Bacterial Interactions and Leads to Colonic Sensory and Motor Changes in Mice. Gut Microbes. 6, 10-23. doi: 10.4161/ 19490976.2014.990790

Aguilera, M., Vergara, P., and Martínez, V. (2013). Stress and Antibiotics Alter Luminal and Wall-Adhered Microbiota and Enhance the Local Expression of Visceral Sensory-Related Systems in Mice. Neurogastroenterol. Motil. 25, e515e529. doi: 10.1111/nmo.12154

Aisenberg, W. H., Huang, J., Zhu, W., Rajkumar, P., Cruz, R., Santhanam, L., et al. (2016). Defining an Olfactory Receptor Function in Airway Smooth Muscle Cells. Sci. Rep. 6, 38231. doi: 10.1038/srep38231

Akiba, Y., Maruta, K., Narimatsu, K., Said, H., Kaji, I., Kuri, A., et al. (2017). FFA2 Activation Combined With Ulcerogenic COX Inhibition Induces Duodenal Mucosal Injury via the 5-HT Pathway in Rats. Am. J. Physiol. Gastrointest. Liver Physiol. 313, G117-g128. doi: 10.1152/ajpgi.00041.2017

Aktar, R., Parkar, N., Stentz, R., Baumard, L., Parker, A., Goldson, A., et al. (2020). Human Resident Gut Microbe Bacteroides Thetaiotaomicron Regulates Colonic Neuronal Innervation and Neurogenic Function. Gut Microbes 11, 1745-1757. doi: 10.1080/19490976.2020.1766936

Amaral, F. A., Sachs, D., Costa, V. V., Fagundes, C. T., Cisalpino, D., Cunha, T. M., et al. (2008). Commensal Microbiota Is Fundamental for the Development of et al., 2016). as a limitation, this review discussed only the role of ECs in hyperalgesia, ignoring the effects of other enteroendocrine cells influenced by the ECs after the disturbance of the gut microbiota. Therefore, it is necessary to further investigate the effects of enteroendocrine cells influenced by the ECs. In addition, different gut microbiota may have different effects on ECs, which need to be further studied.

\section{CONCLUSION}

By sensing different gut microbiota and its metabolites, ECs can activate pain-related receptors and induce the release of 5-HT to transmits pain signals to the brain through the vagus nerve. ECs become sentinels for sensing the gut microbiota to participate in the occurrence of hyperalgesia. Although the characteristics and functions of ECs in vivo still need to be further understood, the existing studies have laid a theoretical foundation for the effect of ECs receptors and 5-HT secreted by ECs on the gut microbiota and hyperalgesia. To continue to explore the underlying mechanism of ECs will be an indispensable and promising challenge in the search for pain treatment strategies in the future.

\section{AUTHOR CONTRIBUTIONS}

XX wrote the manuscript of this review. All authors critically reviewed and approved the final version of the paper.

\section{FUNDING}

This study was supported by a grant from the National Natural Science Foundation of China (Grant No. 81341034).
Inflammatory Pain. Proc. Natl. Acad. Sci. U. S. A. 105, 2193-2197. doi: 10.1073/ pnas.0711891105

Asano, Y., Hiramoto, T., Nishino, R., Aiba, Y., Kimura, T., Yoshihara, K., et al. (2012). Critical Role of Gut Microbiota in the Production of Biologically Active, Free Catecholamines in the Gut Lumen of Mice. Am. J. Physiol. Gastrointest. Liver Physiol. 303, G1288-G1295. doi: 10.1152/ajpgi.00341.2012

Bai, T., Li, Y., Xia, J., Jiang, Y., Zhang, L., Wang, H., et al. (2017). Piezo2: A Candidate Biomarker for Visceral Hypersensitivity in Irritable Bowel Syndrome? J. Neurogastroenterol. Motil. 23, 453-463. doi: 10.5056/jnm16114

Basbaum, A. I., Bautista, D. M., Scherrer, G., and Julius, D. (2009). Cellular and Molecular Mechanisms of Pain. Cell 139, 267-284. doi: 10.1016/ j.cell.2009.09.028

Bautista, D. M., Jordt, S. E., Nikai, T., Tsuruda, P. R., Read, A. J., Poblete, J., et al. (2006). TRPA1 Mediates the Inflammatory Actions of Environmental Irritants and Proalgesic Agents. Cell 124, 1269-1282. doi: 10.1016/j.cell.2006.02.023

Beer, F., Urbat, F., Franz, C., Huch, M., Kulling, S. E., Bunzel, M., et al. (2019). The Human Fecal Microbiota Metabolizes Foodborne Heterocyclic Aromatic Amines by Reuterin Conjugation and Further Transformations. Mol. Nutr. Food Res. 63, e1801177. doi: 10.1002/mnfr.201801177

Bellono, N. W., Bayrer, J. R., Leitch, D. B., Castro, J., Zhang, C., O'donnell, T. A., et al. (2017). Enterochromaffin Cells Are Gut Chemosensors That Couple to Sensory Neural Pathways. Cell 170, 185-198.e116. doi: 10.1016/ j.cell.2017.05.034 
Bi, Z., Zhang, S., Meng, Y., Feng, Y., Wang, Y., Wang, E., et al. (2021). Female Serotonin Transporter-Knockout Rat: A Potential Model of Irritable Bowel Syndrome. FASEB J. 35, e21701. doi: 10.1096/fj.202000007RRR

Blackshaw, L. A. (2014). Transient Receptor Potential Cation Channels in Visceral Sensory Pathways. Br. J. Pharmacol. 171, 2528-2536. doi: 10.1111/bph.12641

Boer, C. G., Radjabzadeh, D., Medina-Gomez, C., Garmaeva, S., Schiphof, D., Arp, P., et al. (2019). Intestinal Microbiome Composition and Its Relation to Joint Pain and Inflammation. Nat. Commun. 10, 4881. doi: 10.1038/s41467-01912873-4

Bohórquez, D. V., Shahid, R. A., Erdmann, A., Kreger, A. M., Wang, Y., Calakos, N., et al. (2015). Neuroepithelial Circuit Formed by Innervation of Sensory Enteroendocrine Cells. J. Clin. Invest. 125, 782-786. doi: 10.1172/jci78361

Bonomo, R. R., Cook, T. M., Gavini, C. K., White, C. R., Jones, J. R., Bovo, E., et al. (2020). Fecal Transplantation and Butyrate Improve Neuropathic Pain, Modify Immune Cell Profile, and Gene Expression in the PNS of Obese Mice. Proc. Natl. Acad. Sci. U. S. A. 117, 26482-26493. doi: 10.1073/pnas.2006065117

Brandon-Mong, G. J., Shaw, G. T., Chen, W. H., Chen, C. C., and Wang, D. (2020). A Network Approach to Investigating the Key Microbes and Stability of Gut Microbial Communities in a Mouse Neuropathic Pain Model. BMC Microbiol. 20, 295. doi: 10.1186/s12866-020-01981-7

Braniste, V., Al-Asmakh, M., Kowal, C., Anuar, F., Abbaspour, A., Tóth, M., et al. (2014). The Gut Microbiota Influences Blood-Brain Barrier Permeability in Mice. Sci. Transl. Med. 6, 263ra158. doi: 10.1126/scitranslmed.3009759

Braundmeier-Fleming, A., Russell, N. T., Yang, W., Nas, M. Y., Yaggie, R. E., Berry, M., et al. (2016). Stool-Based Biomarkers of Interstitial Cystitis/Bladder Pain Syndrome. Sci. Rep. 6, 26083. doi: 10.1038/srep26083

Braun, T., Voland, P., Kunz, L., Prinz, C., and Gratzl, M. (2007). Enterochromaffin Cells of the Human Gut: Sensors for Spices and Odorants. Gastroenterology 132, 1890-1901. doi: 10.1053/j.gastro.2007.02.036

Brierley, S. M., Hughes, P. A., Page, A. J., Kwan, K. Y., Martin, C. M., O'donnell, T. A., et al. (2009). The Ion Channel TRPA1 Is Required for Normal Mechanosensation and Is Modulated by Algesic Stimuli. Gastroenterology 137, 2084-2095.e2083. doi: 10.1053/j.gastro.2009.07.048

Cenac, N., Altier, C., Motta, J. P., D’aldebert, E., Galeano, S., Zamponi, G. W., et al. (2010). Potentiation of TRPV4 Signalling by Histamine and Serotonin: An Important Mechanism for Visceral Hypersensitivity. Gut 59, 481-488. doi: 10.1136/gut.2009.192567

Chen, Z., Luo, J., Li, J., Kim, G., Stewart, A., Urban, J. F. Jr., et al. (2021b). Interleukin-33 Promotes Serotonin Release From Enterochromaffin Cells for Intestinal Homeostasis. Immunity 54, 151-163.e156. doi: 10.1016/ j.immuni.2020.10.014

Chen, P., Wang, C., Ren, Y. N., Ye, Z. J., Jiang, C., and Wu, Z. B. (2021a). Alterations in the Gut Microbiota and Metabolite Profiles in the Context of Neuropathic Pain. Mol. Brain 14, 50. doi: 10.1186/s13041-021-00765-y

Chen, Z., Zhao, H., Fu, N., and Chen, L. (2018). The Diversified Function and Potential Therapy of Ectopic Olfactory Receptors in Non-Olfactory Tissues. J. Cell Physiol. 233, 2104-2115. doi: 10.1002/jcp.25929

Chiu, I. M. (2018). Infection, Pain, and Itch. Neurosci. Bull. 34, 109-119. doi: 10.1007/s12264-017-0098-1

Chiu, I. M., Heesters, B. A., Ghasemlou, N., Von Hehn, C. A., Zhao, F., Tran, J., et al. (2013). Bacteria Activate Sensory Neurons That Modulate Pain and Inflammation. Nature 501, 52-57. doi: 10.1038/nature12479

Clos-Garcia, M., Andrés-Marin, N., Fernández-Eulate, G., Abecia, L., Lavín, J. L., Van Liempd, S., et al. (2019). Gut Microbiome and Serum Metabolome Analyses Identify Molecular Biomarkers and Altered Glutamate Metabolism in Fibromyalgia. EBioMedicine 46, 499-511. doi: 10.1016/j.ebiom.2019.07.031

Cogan, T. A., Thomas, A. O., Rees, L. E., Taylor, A. H., Jepson, M. A., Williams, P. H., et al. (2007). Norepinephrine Increases the Pathogenic Potential of Campylobacter Jejuni. Gut 56, 1060-1065. doi: 10.1136/gut.2006.114926

Collins, J., Borojevic, R., Verdu, E. F., Huizinga, J. D., and Ratcliffe, E. M. (2014). Intestinal Microbiota Influence the Early Postnatal Development of the Enteric Nervous System. Neurogastroenterol. Motil. 26, 98-107. doi: 10.1111/nmo.12236

Coste, B., Mathur, J., Schmidt, M., Earley, T. J., Ranade, S., Petrus, M. J., et al. (2010). Piezo1 and Piezo2 Are Essential Components of Distinct Mechanically Activated Cation Channels. Science 330, 55-60. doi: 10.1126/science.1193270

Cowan, C. S. M., Hoban, A. E., Ventura-Silva, A. P., Dinan, T. G., Clarke, G., and Cryan, J. F. (2018). Gutsy Moves: The Amygdala as a Critical Node in Microbiota to Brain Signaling. Bioessays 40, 1. doi: 10.1002/bies.201700172
Cremon, C., Carini, G., Wang, B., Vasina, V., Cogliandro, R. F., De Giorgio, R., et al. (2011). Intestinal Serotonin Release, Sensory Neuron Activation, and Abdominal Pain in Irritable Bowel Syndrome. Am. J. Gastroenterol. 106, 1290 1298. doi: 10.1038/ajg.2011.86

Crowell, M. D., and Wessinger, S. B. (2007). 5-HT and the Brain-Gut Axis: Opportunities for Pharmacologic Intervention. Expert Opin. Investig. Drugs 16, 761-765. doi: 10.1517/13543784.16.6.761

Cuozzo, M., Castelli, V., Avagliano, C., Cimini, A., D’angelo, M., Cristiano, C., et al. (2021). Effects of Chronic Oral Probiotic Treatment in Paclitaxel-Induced Neuropathic Pain. Biomedicines 9, 346. doi: 10.3390/biomedicines 9040346

Dai, Y. (2016). Trps and Pain. Semin. Immunopathol. 38, 277-291. doi: 10.1007/ s00281-015-0526-0

Dekker Nitert, M., Mousa, A., Barrett, H. L., Naderpoor, N., and De Courten, B. (2020). Altered Gut Microbiota Composition Is Associated With Back Pain in Overweight and Obese Individuals. Front. Endocrinol. (Lausanne) 11, 605. doi: 10.3389/fendo.2020.00605

Deng, F., Zhao, B. C., Yang, X., Lin, Z. B., Sun, Q. S., Wang, Y. F., et al. (2021). The Gut Microbiota Metabolite Capsiate Promotes Gpx4 Expression by Activating TRPV1 to Inhibit Intestinal Ischemia Reperfusion-Induced Ferroptosis. Gut Microbes 13, 1-21. doi: 10.1080/19490976.2021.1902719

Diaz Heijtz, R., Wang, S., Anuar, F., Qian, Y., Björkholm, B., Samuelsson, A., et al. (2011). Normal Gut Microbiota Modulates Brain Development and Behavior. Proc. Natl. Acad. Sci. U. S. A. 108, 3047-3052. doi: 10.1073/pnas.1010529108

Di Giancamillo, A., Vitari, F., Bosi, G., Savoini, G., and Domeneghini, C. (2010). The Chemical Code of Porcine Enteric Neurons and the Number of Enteric Glial Cells Are Altered by Dietary Probiotics. Neurogastroenterol. Motil. 22, e271-e278. doi: 10.1111/j.1365-2982.2010.01529.x

Ding, W., You, Z., Chen, Q., Yang, L., Doheny, J., Zhou, X., et al. (2021). Gut Microbiota Influences Neuropathic Pain Through Modulating Proinflammatory and Anti-Inflammatory T Cells. Anesth. Analg. 132, 11461155. doi: 10.1213/ane.0000000000005155

Dinić, M., Pecikoza, U., Djokić, J., Stepanović-Petrović, R., Milenković, M., Stevanović, M., et al. (2018). Exopolysaccharide Produced by Probiotic Strain Lactobacillus Paraplantarum BGCG11 Reduces Inflammatory Hyperalgesia in Rats. Front. Pharmacol. 9, 1. doi: 10.3389/fphar.2018.00001

Distrutti, E., Cipriani, S., Mencarelli, A., Renga, B., and Fiorucci, S. (2013). Probiotics VSL3 Protect Against Development of Visceral Pain in Murine Model of Irritable Bowel Syndrome. PloS One 8, e63893. doi: 10.1371/ journal.pone.0063893

Di, W., Zhang, L., Wang, S., Yi, H., Han, X., Fan, R., et al. (2017). Physicochemical Characterization and Antitumour Activity of Exopolysaccharides Produced by Lactobacillus Casei SB27 From Yak Milk. Carbohydr. Polym. 171, 307-315. doi: 10.1016/j.carbpol.2017.03.018

Dolgorukova, A., Isaeva, J. E., Verbitskaya, E., Lyubashina, O. A., Giniatullin, R., and Sokolov, A. Y. (2021). Differential Effects of the Piezol Agonist Yoda1 in the Trigeminovascular System: An Electrophysiological and Intravital Microscopy Study in Rats. Exp. Neurol. 339, 113634. doi: 10.1016/ j.expneurol.2021.113634

Duncker, S. C., Wang, L., Hols, P., and Bienenstock, J. (2008). The D-Alanine Content of Lipoteichoic Acid Is Crucial for Lactobacillus Plantarum-Mediated Protection From Visceral Pain Perception in a Rat Colorectal Distension Model. Neurogastroenterol. Motil. 20, 843-850. doi: 10.1111/j.13652982.2008.01085.x

Eijkelkamp, N., Linley, J. E., Torres, J. M., Bee, L., Dickenson, A. H., Gringhuis, M., et al. (2013). A Role for Piezo2 in EPAC1-Dependent Mechanical Allodynia. Nat. Commun. 4, 1682. doi: 10.1038/ncomms 2673

Erny, D., Hrabě De Angelis, A. L., Jaitin, D., Wieghofer, P., Staszewski, O., David, E., et al. (2015). Host Microbiota Constantly Control Maturation and Function of Microglia in the CNS. Nat. Neurosci. 18, 965-977. doi: 10.1038/nn.4030

Fattahi, F., Steinbeck, J. A., Kriks, S., Tchieu, J., Zimmer, B., Kishinevsky, S., et al. (2016). Deriving Human ENS Lineages for Cell Therapy and Drug Discovery in Hirschsprung Disease. Nature 531, 105-109. doi: 10.1038/nature16951

Fernández-Trillo, J., Florez-Paz, D., Íñigo-Portugués, A., González-González, O., Del Campo, A. G., González, A., et al. (2020). Piezo2 Mediates Low-Threshold Mechanically Evoked Pain in the Cornea. J. Neurosci. 40, 8976-8993. doi: 10.1523/jneurosci.0247-20.2020

Freidin, M. B., Stalteri, M. A., Wells, P. M., Lachance, G., Baleanu, A. F., Bowyer, R. C. E., et al. (2021). An Association Between Chronic Widespread Pain and 
the Gut Microbiome. Rheumatol. (Oxford) 60, 3727-3737. doi: 10.1093/ rheumatology/keaa847

Gao, J., Gillilland, M. G. 3rd, and Owyang, C. (2014). Rifaximin, Gut Microbes and Mucosal Inflammation: Unraveling a Complex Relationship. Gut Microbes 5, 571-575. doi: 10.4161/gmic.32130

Gershon, M. D. (2013). 5-Hydroxytryptamine (Serotonin) in the Gastrointestinal Tract. Curr. Opin. Endocrinol. Diabetes Obes. 20, 14-21. doi: 10.1097/ MED.0b013e32835bc703

Gross, E. R., Gershon, M. D., Margolis, K. G., Gertsberg, Z. V., Li, Z., and Cowles, R. A. (2012). Neuronal Serotonin Regulates Growth of the Intestinal Mucosa in Mice. Gastroenterology 143, 408-417.e402. doi: 10.1053/j.gastro.2012.05.007

Guglielmetti, S., Mora, D., Gschwender, M., and Popp, K. (2011). Randomised Clinical Trial: Bifidobacterium Bifidum Mimbb75 Significantly Alleviates Irritable Bowel Syndrome and Improves Quality of Life-A Double-Blind, Placebo-Controlled Study. Aliment Pharmacol. Ther. 33, 1123-1132. doi: 10.1111/j.1365-2036.2011.04633.x

Guida, F., Boccella, S., Belardo, C., Iannotta, M., Piscitelli, F., De Filippis, F., et al. (2020). Altered Gut Microbiota and Endocannabinoid System Tone in Vitamin D Deficiency-Mediated Chronic Pain. Brain Behav. Immun. 85, 128-141. doi: 10.1016/j.bbi.2019.04.006

Guo, R., Chen, L. H., Xing, C., and Liu, T. (2019). Pain Regulation by Gut Microbiota: Molecular Mechanisms and Therapeutic Potential. Br. J. Anaesth. 123, 637-654. doi: 10.1016/j.bja.2019.07.026

Guo, J., Gu, D., Zhao, T., Zhao, Z., Xiong, Y., Sun, M., et al. (2021). Trends in Piezo Channel Research Over the Past Decade: A Bibliometric Analysis. Front. Pharmacol. 12, 668714. doi: 10.3389/fphar.2021.668714

Han, P., Zhao, J., Liu, S. B., Yang, C. J., Wang, Y. Q., Wu, G. C., et al. (2013). Interleukin-33 Mediates Formalin-Induced Inflammatory Pain in Mice. Neuroscience 241, 59-66. doi: 10.1016/j.neuroscience.2013.03.019

Hayashi, F., Smith, K. D., Ozinsky, A., Hawn, T. R., Yi, E. C., Goodlett, D. R., et al. (2001). The Innate Immune Response to Bacterial Flagellin Is Mediated by Toll-Like Receptor 5. Nature 410, 1099-1103. doi: 10.1038/35074106

Hegde, S., Lin, Y. M., Fu, Y., Savidge, T., and Shi, X. Z. (2020). Precision Lactobacillus Reuteri Therapy Attenuates Luminal Distension-Associated Visceral Hypersensitivity by Inducing Peripheral Opioid Receptors in the Colon. Pain 161, 2737-2749. doi: 10.1097/j.pain.0000000000001967

Hoban, A. E., Stilling, R. M., Moloney, G. M., Moloney, R. D., Shanahan, F., Dinan, T. G., et al. (2017). Microbial Regulation of Microrna Expression in the Amygdala and Prefrontal Cortex. Microbiome 5, 102. doi: 10.1186/s40168017-0321-3

Holzer, P., and Farzi, A. (2014). Neuropeptides and the Microbiota-Gut-Brain Axis. Adv. Exp. Med. Biol. 817, 195-219. doi: 10.1007/978-1-4939-0897-4_9

Hosseinifard, E. S., Morshedi, M., Bavafa-Valenlia, K., and Saghafi-Asl, M. (2019). The Novel Insight Into Anti-Inflammatory and Anxiolytic Effects of Psychobiotics in Diabetic Rats: Possible Link Between Gut Microbiota and Brain Regions. Eur. J. Nutr. 58, 3361-3375. doi: 10.1007/s00394-019-01924-7

Hosseinkhani, F., Heinken, A., Thiele, I., Lindenburg, P. W., Harms, A. C., and Hankemeier, T. (2021). The Contribution of Gut Bacterial Metabolites in the Human Immune Signaling Pathway of Non-Communicable Diseases. Gut Microbes 13, 1-22. doi: 10.1080/19490976.2021.1882927

Hua, P., Xiong, Y., Yu, Z., Liu, B., and Zhao, L. (2019). Effect of Chlorella Pyrenoidosa Protein Hydrolysate-Calcium Chelate on Calcium Absorption Metabolism and Gut Microbiota Composition in Low-Calcium Diet-Fed Rats. Mar Drugs 17, 348. doi: 10.3390/md17060348

Hun, L. (2009). Bacillus Coagulans Significantly Improved Abdominal Pain and Bloating in Patients With IBS. Postgrad. Med. 121, 119-124. doi: 10.3810/ pgm.2009.03.1984

Huynh, K. (2020). Novel Gut Microbiota-Derived Metabolite Promotes Platelet Thrombosis via Adrenergic Receptor Signalling. Nat. Rev. Cardiol. 17, 265. doi: 10.1038/s41569-020-0367-y

Hyland, N. P., and Cryan, J. F. (2016). Microbe-Host Interactions: Influence of the Gut Microbiota on the Enteric Nervous System. Dev. Biol. 417, 182-187. doi: 10.1016/j.ydbio.2016.06.027

Jadrešin, O., Hojsak, I., Mišak, Z., Kekez, A. J., Trbojević, T., Ivković, L., et al. (2017). Lactobacillus Reuteri DSM 17938 in the Treatment of Functional Abdominal Pain in Children: RCT Study. J. Pediatr. Gastroenterol. Nutr. 64, 925-929. doi: 10.1097/mpg.0000000000001478
Jadrešin, O., Sila, S., Trivić, I., Mišak, Z., Kolaček, S., and Hojsak, I. (2020). Lactobacillus Reuteri DSM 17938 Is Effective in the Treatment of Functional Abdominal Pain in Children: Results of the Double-Blind Randomized Study. Clin. Nutr. 39, 3645-3651. doi: 10.1016/j.clnu.2020.04.019

Jhun, J., Cho, K. H., Lee, D. H., Kwon, J. Y., Woo, J. S., Kim, J., et al. (2021). Oral Administration of Lactobacillus Rhamnosus Ameliorates the Progression of Osteoarthritis by Inhibiting Joint Pain and Inflammation. Cells 10, 1057. doi: $10.3390 /$ cells 10051057

Jiang, Y., Yang, X., Jiang, J., and Xiao, B. (2021). Structural Designs and Mechanogating Mechanisms of the Mechanosensitive Piezo Channels. Trends Biochem. Sci. 46, 472-488. doi: 10.1016/j.tibs.2021.01.008

Kamm, K., Hoppe, S., Breves, G., Schröder, B., and Schemann, M. (2004). Effects of the Probiotic Yeast Saccharomyces Boulardii on the Neurochemistry of Myenteric Neurones in Pig Jejunum. Neurogastroenterol. Motil. 16, 53-60. doi: 10.1046/j.1365-2982.2003.00458.x

Karsenty, G., and Yadav, V. K. (2011). Regulation of Bone Mass by Serotonin: Molecular Biology and Therapeutic Implications. Annu. Rev. Med. 62, 323331. doi: 10.1146/annurev-med-090710-133426

Kawase, T., Nagasawa, M., Ikeda, H., Yasuo, S., Koga, Y., and Furuse, M. (2017). Gut Microbiota of Mice Putatively Modifies Amino Acid Metabolism in the Host Brain. Br. J. Nutr. 117, 775-783. doi: 10.1017/s0007114517000678

Kim, S. E., Coste, B., Chadha, A., Cook, B., and Patapoutian, A. (2012). The Role of Drosophila Piezo in Mechanical Nociception. Nature 483, 209-212. doi: 10.1038/nature10801

Kremeyer, B., Lopera, F., Cox, J. J., Momin, A., Rugiero, F., Marsh, S., et al. (2010). A Gain-of-Function Mutation in TRPA1 Causes Familial Episodic Pain Syndrome. Neuron 66, 671-680. doi: 10.1016/j.neuron.2010.04.030

Lee, E., Takita, C., Wright, J. L., Slifer, S. H., Martin, E. R., Urbanic, J. J., et al. (2019). Genome-Wide Enriched Pathway Analysis of Acute Post-Radiotherapy Pain in Breast Cancer Patients: A Prospective Cohort Study. Hum. Genomics 13, 28. doi: 10.1186/s40246-019-0212-8

Lian, N., Shen, M., Zhang, K., Pan, J., Jiang, Y., Yu, Y., et al. (2021). Drinking Hydrogen-Rich Water Alleviates Chemotherapy-Induced Neuropathic Pain Through the Regulation of Gut Microbiota. J. Pain Res. 14, 681-691. doi: $10.2147 /$ jpr.s288289

Lieder, B., Hoi, J., Burian, N., Hans, J., Holik, A. K., Beltran Marquez, L. R., et al. (2020). Structure-Dependent Effects of Cinnamaldehyde Derivatives on TRPA1-Induced Serotonin Release in Human Intestinal Cell Models. J. Agric. Food Chem. 68, 3924-3932. doi: 10.1021/acs.jafc.9b08163

Liñán-Rico, A., Ochoa-Cortes, F., Zuleta-Alarcon, A., Alhaj, M., Tili, E., Enneking, J., et al. (2017). UTP - Gated Signaling Pathways of 5-HT Release From BON Cells as a Model of Human Enterochromaffin Cells. Front. Pharmacol. 8, 429. doi: $10.3389 /$ fphar.2017.00429

Liu, Y., Li, W., Yang, H., Zhang, X., Wang, W., Jia, S., et al. (2021b). Leveraging $16 S$ Rrna Microbiome Sequencing Data to Identify Bacterial Signatures for Irritable Bowel Syndrome. Front. Cell Infect. Microbiol. 11, 645951. doi: 10.3389/ fcimb.2021.645951

Liu, M., Li, Y., Zhong, J., Xia, L., and Dou, N. (2021a). The Effect of IL-6/Piezo2 on the Trigeminal Neuropathic Pain. Aging (Albany NY) 13, 13615-13625. doi: 10.18632/aging.202887

Liu, Y. W., Wang, Y. P., Yen, H. F., Liu, P. Y., Tzeng, W. J., Tsai, C. F., et al. (2020), Lactobacillus Plantarum PS128 Ameliorated Visceral Hypersensitivity in Rats Through the Gut-Brain Axis. Probiotics Antimicrob. Proteins 12, 980-993. doi: 10.1007/s12602-019-09595-w

Logashina, Y. A., Korolkova, Y. V., Kozlov, S. A., and Andreev, Y. A. (2019). TRPA1 Channel as a Regulator of Neurogenic Inflammation and Pain: Structure, Function, Role in Pathophysiology, and Therapeutic Potential of Ligands. Biochem. (Mosc) 84, 101-118. doi: 10.1134/s0006297919020020

Luczynski, P., Tramullas, M., Viola, M., Shanahan, F., Clarke, G., O'mahony, S., et al. (2017). Microbiota Regulates Visceral Pain in the Mouse. Elife 6, e25887. doi: $10.7554 /$ eLife. 25887

Lu, J., Synowiec, S., Lu, L., Yu, Y., Bretherick, T., Takada, S., et al. (2018). Microbiota Influence the Development of the Brain and Behaviors in C57BL/6J Mice. PloS One 13, e0201829. doi: 10.1371/journal.pone.0201829

Lv, W., Graves, D. T., He, L., Shi, Y., Deng, X., Zhao, Y., et al. (2020). Depletion of the Diabetic Gut Microbiota Resistance Enhances Stem Cells Therapy in Type 1 Diabetes Mellitus. Theranostics 10, 6500-6516. doi: 10.7150/thno.44113 
Maeda, H., Zhu, X., Omura, K., Suzuki, S., and Kitamura, S. (2004). Effects of an Exopolysaccharide (Kefiran) on Lipids, Blood Pressure, Blood Glucose, and Constipation. Biofactors 22, 197-200. doi: 10.1002/biof.5520220141

Ma, Y., Liu, S., Shu, H., Crawford, J., Xing, Y., and Tao, F. (2020). Resveratrol Alleviates Temporomandibular Joint Inflammatory Pain by Recovering Disturbed Gut Microbiota. Brain Behav. Immun. 87, 455-464. doi: 10.1016/ j.bbi.2020.01.016

Matsumoto, M., Kibe, R., Ooga, T., Aiba, Y., Sawaki, E., Koga, Y., et al. (2013). Cerebral Low-Molecular Metabolites Influenced by Intestinal Microbiota: A Pilot Study. Front. Syst. Neurosci. 7, 9. doi: 10.3389/fnsys.2013.00009

Matthes, S., and Bader, M. (2018). Peripheral Serotonin Synthesis as a New Drug Target. Trends Pharmacol. Sci. 39, 560-572. doi: 10.1016/j.tips.2018.03.004

Mckernan, D. P., Fitzgerald, P., Dinan, T. G., and Cryan, J. F. (2010). The Probiotic Bifidobacterium Infantis 35624 Displays Visceral Antinociceptive Effects in the Rat. Neurogastroenterol. Motil. 22, 1029-1035, e1268. doi: 10.1111/j.13652982.2010.01520.x

Mcvey Neufeld, K. A., Mao, Y. K., Bienenstock, J., Foster, J. A., and Kunze, W. A. (2013). The Microbiome Is Essential for Normal Gut Intrinsic Primary Afferent Neuron Excitability in the Mouse. Neurogastroenterol. Motil. 25, 183-e188. doi: 10.1111/nmo.12049

Meijerink, J. (2021). The Intestinal Fatty Acid-Enteroendocrine Interplay, Emerging Roles for Olfactory Signaling and Serotonin Conjugates. Molecules 26, 1416. doi: 10.3390/molecules26051416

Meseguer, V., Alpizar, Y. A., Luis, E., Tajada, S., Denlinger, B., Fajardo, O., et al. (2014). TRPA1 Channels Mediate Acute Neurogenic Inflammation and Pain Produced by Bacterial Endotoxins. Nat. Commun. 5, 3125. doi: 10.1038/ ncomms 4125

Mikhailov, N., Leskinen, J., Fagerlund, I., Poguzhelskaya, E., Giniatullina, R., Gafurov, O., et al. (2019). Mechanosensitive Meningeal Nociception via Piezo Channels: Implications for Pulsatile Pain in Migraine? Neuropharmacology 149, 113-123. doi: 10.1016/j.neuropharm.2019.02.015

Nascimento, E. B. Jr., Romero, T. R. L., Dutra, M., Fiebich, B. L., Duarte, I. D. G., and Coelho, M. M. (2021). Role of Peripheral 5-HT(1D), 5-HT(3) and 5-HT(7) Receptors in the Mechanical Allodynia Induced by Serotonin in Mice. BioMed. Pharmacother. 135, 111210. doi: 10.1016/j.biopha.2020.111210

Nilius, B., and Owsianik, G. (2011). The Transient Receptor Potential Family of Ion Channels. Genome Biol. 12, 218. doi: 10.1186/gb-2011-12-3-218

Nilius, B., and Szallasi, A. (2014). Transient Receptor Potential Channels as Drug Targets: From the Science of Basic Research to the Art of Medicine. Pharmacol. Rev. 66, 676-814. doi: 10.1124/pr.113.008268

Nishida, A., Miyamoto, J., Shimizu, H., and Kimura, I. (2021). Gut Microbial Short-Chain Fatty Acids-Mediated Olfactory Receptor 78 Stimulation Promotes Anorexigenic Gut Hormone Peptide YY Secretion in Mice. Biochem. Biophys. Res. Commun. 557, 48-54. doi: 10.1016/j.bbrc.2021.03.167

Ni, K., Zhang, W., Ni, Y., Mao, Y. T., Wang, Y., Gu, X. P., et al. (2021). Dorsal Root Ganglia NR2B-Mediated Epac1-Piezo2 Signaling Pathway Contributes to Mechanical Allodynia of Bone Cancer Pain. Oncol. Lett. 21, 338. doi: 10.3892/ol.2021.12599

Nozawa, K., Kawabata-Shoda, E., Doihara, H., Kojima, R., Okada, H., Mochizuki, S., et al. (2009). TRPA1 Regulates Gastrointestinal Motility Through Serotonin Release From Enterochromaffin Cells. Proc. Natl. Acad. Sci. U. S. A. 106, $3408-$ 3413. doi: $10.1073 /$ pnas.0805323106

Nugraha, B., Gutenbrunner, C., Barke, A., Karst, M., Schiller, J., Schäfer, P., et al. (2019). The IASP Classification of Chronic Pain for ICD-11: Functioning Properties of Chronic Pain. Pain 160, 88-94. doi: 10.1097/j.pain. 0000000000001433

Ochoa-Cortes, F., Ramos-Lomas, T., Miranda-Morales, M., Spreadbury, I., Ibeakanma, C., Barajas-Lopez, C., et al. (2010). Bacterial Cell Products Signal to Mouse Colonic Nociceptive Dorsal Root Ganglia Neurons. Am. J. Physiol. Gastrointest. Liver Physiol. 299, G723-G732. doi: 10.1152/ajpgi.00494.2009

Ohira, H., Tsutsui, W., and Fujioka, Y. (2017). Are Short Chain Fatty Acids in Gut Microbiota Defensive Players for Inflammation and Atherosclerosis? J. Atheroscler. Thromb. 24, 660-672. doi: 10.5551/jat.RV17006

O'mahony, S. M., Felice, V. D., Nally, K., Savignac, H. M., Claesson, M. J., Scully, P., et al. (2014). Disturbance of the Gut Microbiota in Early-Life Selectively Affects Visceral Pain in Adulthood Without Impacting Cognitive or AnxietyRelated Behaviors in Male Rats. Neuroscience 277, 885-901. doi: 10.1016/ j.neuroscience.2014.07.054
O’mahony, S. M., Hyland, N. P., Dinan, T. G., and Cryan, J. F. (2011). Maternal Separation as a Model of Brain-Gut Axis Dysfunction. Psychopharmacol. (Berl) 214, 71-88. doi: 10.1007/s00213-010-2010-9

Pagano, E., Romano, B., Iannotti, F. A., Parisi, O. A., D’armiento, M., Pignatiello, S., et al. (2019). The Non-Euphoric Phytocannabinoid Cannabidivarin Counteracts Intestinal Inflammation in Mice and Cytokine Expression in Biopsies From UC Pediatric Patients. Pharmacol. Res. 149, 104464. doi: 10.1016/j.phrs.2019.104464

Pan, H., and Gershon, M.D. (2000). Activation of Intrinsic Afferent Pathways in Submucosal Ganglia of the Guinea Pig Small Intestine. J. Neurosci. 20, 32953309. doi: 10.1523/jneurosci.20-09-03295.2000

Pellegrini, C., Antonioli, L., Colucci, R., Blandizzi, C., and Fornai, M. (2018). Interplay Among Gut Microbiota, Intestinal Mucosal Barrier and Enteric Neuro-Immune System: A Common Path to Neurodegenerative Diseases? Acta Neuropathol. 136, 345-361. doi: 10.1007/s00401-018-1856-5

Philip, V., Newton, D. F., Oh, H., Collins, S. M., Bercik, P., and Sibille, E. (2021). Transcriptional Markers of Excitation-Inhibition Balance in Germ-Free Mice Show Region-Specific Dysregulation and Rescue After Bacterial Colonization. J. Psychiatr. Res. 135, 248-255. doi: 10.1016/j.jpsychires.2021.01.021

Pluznick, J. (2014). A Novel SCFA Receptor, the Microbiota, and Blood Pressure Regulation. Gut Microbes 5, 202-207. doi: 10.4161/gmic.27492

Pluznick, J. L., Protzko, R. J., Gevorgyan, H., Peterlin, Z., Sipos, A., Han, J., et al. (2013). Olfactory Receptor Responding to Gut Microbiota-Derived Signals Plays a Role in Renin Secretion and Blood Pressure Regulation. Proc. Natl. Acad. Sci. U. S. A. 110, 4410-4415. doi: 10.1073/pnas.1215927110

Qin, H. Y., Zang, K. H., Zuo, X., Wu, X. A., and Bian, Z. X. (2019). Quercetin Attenuates Visceral Hypersensitivity and 5-Hydroxytryptamine Availability in Postinflammatory Irritable Bowel Syndrome Rats: Role of Enterochromaffin Cells in the Colon. J. Med. Food 22, 663-671. doi: 10.1089/jmf.2018.4264

Ramakrishna, C., Corleto, J., Ruegger, P. M., Logan, G. D., Peacock, B. B., Mendonca, S., et al. (2019). Dominant Role of the Gut Microbiota in Chemotherapy Induced Neuropathic Pain. Sci. Rep. 9, 20324. doi: 10.1038/ s41598-019-56832-x

Ranade, S. S., Qiu, Z., Woo, S. H., Hur, S. S., Murthy, S. E., Cahalan, S. M., et al. (2014a). Piezo1, a Mechanically Activated Ion Channel, Is Required for Vascular Development in Mice. Proc. Natl. Acad. Sci. U. S. A. 111, 1034710352. doi: 10.1073/pnas.1409233111

Ranade, S. S., Woo, S. H., Dubin, A. E., Moshourab, R. A., Wetzel, C., Petrus, M., et al. (2014b). Piezo2 Is the Major Transducer of Mechanical Forces for Touch Sensation in Mice. Nature 516, 121-125. doi: 10.1038/nature13980

Reyes-Gibby, C. C., Wang, J., Silvas, M. R., Yu, R. K., Hanna, E. Y., and Shete, S. (2016). Genome-Wide Association Study Suggests Common Variants Within RP11-634B7.4 Gene Influencing Severe Pre-Treatment Pain in Head and Neck Cancer Patients. Sci. Rep. 6, 34206. doi: 10.1038/srep34206

Rhee, S. H., Pothoulakis, C., and Mayer, E. A. (2009). Principles and Clinical Implications of the Brain-Gut-Enteric Microbiota Axis. Nat. Rev. Gastroenterol. Hepatol. 6, 306-314. doi: 10.1038/nrgastro.2009.35

Ringel-Kulka, T., Goldsmith, J. R., Carroll, I. M., Barros, S. P., Palsson, O., Jobin, C., et al. (2014). Lactobacillus Acidophilus NCFM Affects Colonic Mucosal Opioid Receptor Expression in Patients With Functional Abdominal Pain - A Randomised Clinical Study. Aliment Pharmacol. Ther. 40, 200-207. doi: 10.1111/apt.12800

Romano, C., Ferrau, V., Cavataio, F., Iacono, G., Spina, M., Lionetti, E., et al. (2014). Lactobacillus Reuteri in Children With Functional Abdominal Pain (FAP). J. Paediatr. Child Health 50, E68-E71. doi: 10.1111/j.1440-1754.2010.01797.x

Rosser, E. C., Piper, C. J. M., Matei, D. E., Blair, P. A., Rendeiro, A. F., Orford, M., et al. (2020). Microbiota-Derived Metabolites Suppress Arthritis by Amplifying Aryl-Hydrocarbon Receptor Activation in Regulatory B Cells. Cell Metab. 31, 837-851.e810. doi: 10.1016/j.cmet.2020.03.003

Rousseaux, C., Thuru, X., Gelot, A., Barnich, N., Neut, C., Dubuquoy, L., et al. (2007). Lactobacillus Acidophilus Modulates Intestinal Pain and Induces Opioid and Cannabinoid Receptors. Nat. Med. 13, 35-37. doi: 10.1038/nm1521

Santoni, M., Miccini, F., and Battelli, N. (2021). Gut Microbiota, Immunity and Pain. Immunol. Lett. 229, 44-47. doi: 10.1016/j.imlet.2020.11.010

Saulnier, D. M., Riehle, K., Mistretta, T. A., Diaz, M. A., Mandal, D., Raza, S., et al. (2011). Gastrointestinal Microbiome Signatures of Pediatric Patients With Irritable Bowel Syndrome. Gastroenterology 141, 1782-1791. doi: 10.1053/ j.gastro.2011.06.072 
Shen, S., Lim, G., You, Z., Ding, W., Huang, P., Ran, C., et al. (2017). Gut Microbiota Is Critical for the Induction of Chemotherapy-Induced Pain. Nat. Neurosci. 20, 1213-1216. doi: 10.1038/nn.4606

Singhmar, P., Huo, X., Eijkelkamp, N., Berciano, S. R., Baameur, F., Mei, F. C., et al. (2016). Critical Role for Epacl in Inflammatory Pain Controlled by GRK2-Mediated Phosphorylation of Epac1. Proc. Natl. Acad. Sci. U. S. A. 113, 3036-3041. doi: 10.1073/pnas.1516036113

Souza, D. G., Vieira, A. T., Soares, A. C., Pinho, V., Nicoli, J. R., Vieira, L. Q., et al. (2004). The Essential Role of the Intestinal Microbiota in Facilitating Acute Inflammatory Responses. J. Immunol. 173, 4137-4146. doi: 10.4049/ jimmunol.173.6.4137

Spiller, R., Pélerin, F., Cayzeele Decherf, A., Maudet, C., Housez, B., Cazaubiel, M., et al. (2016). Randomized Double Blind Placebo-Controlled Trial of Saccharomyces Cerevisiae CNCM I-3856 in Irritable Bowel Syndrome: Improvement in Abdominal Pain and Bloating in Those With Predominant Constipation. United Eur. Gastroenterol. J. 4, 353-362. doi: 10.1177/ 2050640615602571

Sugisawa, E., Takayama, Y., Takemura, N., Kondo, T., Hatakeyama, S., Kumagai, Y., et al. (2020). RNA Sensing by Gut Piezol Is Essential for Systemic Serotonin Synthesis. Cell 182, 609-624.e621. doi: 10.1016/j.cell.2020.06.022

Sun, N., Hu, H., Wang, F., Li, L., Zhu, W., Shen, Y., et al. (2021). Antibiotic-Induced Microbiome Depletion in Adult Mice Disrupts Blood-Brain Barrier and Facilitates Brain Infiltration of Monocytes After Bone-Marrow Transplantation. Brain Behav. Immun. 92, 102-114. doi: 10.1016/j.bbi.2020.11.032

Syeda, R., Florendo, M. N., Cox, C. D., Kefauver, J. M., Santos, J. S., Martinac, B., et al. (2016). Piezo1 Channels Are Inherently Mechanosensitive. Cell Rep. 17, 1739-1746. doi: 10.1016/j.celrep.2016.10.033

Tang, W., Dong, M., Wang, W., Han, S., Rui, X., Chen, X., et al. (2017). Structural Characterization and Antioxidant Property of Released Exopolysaccharides From Lactobacillus Delbrueckii Ssp. Bulgaricus SRFM-1. Carbohydr. Polym. 173, 654-664. doi: 10.1016/j.carbpol.2017.06.039

Tillisch, K., Labus, J., Kilpatrick, L., Jiang, Z., Stains, J., Ebrat, B., et al. (2013). Consumption of Fermented Milk Product With Probiotic Modulates Brain Activity. Gastroenterology 144, 1394-1401, 1401.e1391-1394. doi: 10.1053/ j.gastro.2013.02.043

Treede, R. D., Meyer, R. A., Raja, S. N., and Campbell, J. N. (1992). Peripheral and Central Mechanisms of Cutaneous Hyperalgesia. Prog. Neurobiol. 38, 397-421. doi: 10.1016/0301-0082(92)90027-c

Verdú, E. F., Bercik, P., Verma-Gandhu, M., Huang, X. X., Blennerhassett, P., Jackson, W., et al. (2006). Specific Probiotic Therapy Attenuates Antibiotic Induced Visceral Hypersensitivity in Mice. Gut 55, 182-190. doi: 10.1136/gut.2005.066100

Wang, F., Knutson, K., Alcaino, C., Linden, D. R., Gibbons, S. J., Kashyap, P., et al. (2017a). Mechanosensitive Ion Channel Piezo2 Is Important for Enterochromaffin Cell Response to Mechanical Forces. J. Physiol. 595, 79-91. doi: $10.1113 /$ jp272718

Wang, P., Tu, K., Cao, P., Yang, Y., Zhang, H., Qiu, X. T., et al. (2021a). Antibiotics-Induced Intestinal Dysbacteriosis Caused Behavioral Alternations and Neuronal Activation in Different Brain Regions in Mice. Mol. Brain 14, 49. doi: 10.1186/s13041-021-00759-w

Wang, P., Tu, K., Cao, P., Yang, Y., Zhang, H., Qiu, X. T., et al. (2021b). Correction to: Antibiotics-Induced Intestinal Dysbacteriosis Caused Behavioral Alternations and Neuronal Activation in Different Brain Regions in Mice. Mol. Brain 14, 69. doi: 10.1186/s13041-021-00781-y

Wang, H., Xie, M., Charpin-El Hamri, G., Ye, H., and Fussenegger, M. (2018). Treatment of Chronic Pain by Designer Cells Controlled by Spearmint Aromatherapy. Nat. BioMed. Eng. 2, 114-123. doi: 10.1038/s41551-018-0192-3

Wang, W., Xin, H., Fang, X., Dou, H., Liu, F., Huang, D., et al. (2017b). IsomaltoOligosaccharides Ameliorate Visceral Hyperalgesia With Repair Damage of Ileal Epithelial Ultrastructure in Rats. PloS One 12, e0175276. doi: 10.1371/ journal.pone.0175276

Weizman, Z., Abu-Abed, J., and Binsztok, M. (2016). Lactobacillus Reuteri DSM 17938 for the Management of Functional Abdominal Pain in Childhood: A Randomized, Double-Blind, Placebo-Controlled Trial. J. Pediatr. 174, 160164.e161. doi: 10.1016/j.jpeds.2016.04.003

Wen, J., Bo, T., Zhang, X., Wang, Z., and Wang, D. (2020). Thermo-Trps and Gut Microbiota Are Involved in Thermogenesis and Energy Metabolism During Low Temperature Exposure of Obese Mice. J. Exp. Biol. 223, jeb218974. doi: $10.1242 /$ jeb. 218974
Wikoff, W. R., Anfora, A. T., Liu, J., Schultz, P. G., Lesley, S. A., Peters, E. C., et al. (2009). Metabolomics Analysis Reveals Large Effects of Gut Microflora on Mammalian Blood Metabolites. Proc. Natl. Acad. Sci. U. S. A. 106, 3698-3703. doi: $10.1073 /$ pnas.0812874106

Wood, J. D. (2020). Serotonergic Integration in the Intestinal Mucosa. Curr Pharm. Des. 26, 3010-3014. doi: 10.2174/1381612826666200612161542

Xu, D., Gao, J., Gillilland, M. 3rd, Wu, X., Song, I., Kao, J. Y., et al. (2014). Rifaximin Alters Intestinal Bacteria and Prevents Stress-Induced Gut Inflammation and Visceral Hyperalgesia in Rats. Gastroenterology 146, 484496.e484. doi: 10.1053/j.gastro.2013.10.026

Xu, H. M., Huang, H. L., Zhou, Y. L., Zhao, H. L., Xu, J., Shou, D. W., et al. (2021). Fecal Microbiota Transplantation: A New Therapeutic Attempt From the Gut to the Brain. Gastroenterol. Res. Pract. 2021, 6699268. doi: 10.1155/2021/ 6699268

Xu, X., Hu, Y., Yan, E., Zhan, G., Liu, C., and Yang, C. (2020). Perioperative Neurocognitive Dysfunction: Thinking From the Gut? Aging (Albany NY) 12, 15797-15817. doi: 10.18632/aging.103738

Xu, Z. Z., Kim, Y. H., Bang, S., Zhang, Y., Berta, T., Wang, F., et al. (2015). Inhibition of Mechanical Allodynia in Neuropathic Pain by TLR5-Mediated aFiber Blockade. Nat. Med. 21, 1326-1331. doi: 10.1038/nm.3978

Xu, G. Y., Shenoy, M., Winston, J. H., Mittal, S., and Pasricha, P. J. (2008). P2X Receptor-Mediated Visceral Hyperalgesia in a Rat Model of Chronic Visceral Hypersensitivity. Gut 57, 1230-1237. doi: 10.1136/gut.2007.134221

Yang, C., Fang, X., Zhan, G., Huang, N., Li, S., Bi, J., et al. (2019). Key Role of Gut Microbiota in Anhedonia-Like Phenotype in Rodents With Neuropathic Pain. Transl. Psychiatry 9, 57. doi: 10.1038/s41398-019-0379-8

Yano, J. M., Yu, K., Donaldson, G. P., Shastri, G. G., Ann, P., Ma, L., et al. (2015). Indigenous Bacteria From the Gut Microbiota Regulate Host Serotonin Biosynthesis. Cell 161, 264-276. doi: 10.1016/j.cell.2015.02.047

Yoon, J. S., Sohn, W., Lee, O. Y., Lee, S. P., Lee, K. N., Jun, D. W., et al. (2014). Effect of Multispecies Probiotics on Irritable Bowel Syndrome: A Randomized, Double-Blind, Placebo-Controlled Trial. J. Gastroenterol. Hepatol. 29, 52-59. doi: 10.1111/jgh.12322

Yu, Y., Daly, D. M., Adam, I. J., Kitsanta, P., Hill, C. J., Wild, J., et al. (2016). Interplay Between Mast Cells, Enterochromaffin Cells, and Sensory Signaling in the Aging Human Bowel. Neurogastroenterol. Motil. 28, 1465-1479. doi: $10.1111 /$ nmo.12842

Zhang, J., Bi, J. J., Guo, G. J., Yang, L., Zhu, B., Zhan, G. F., et al. (2019). Abnormal Composition of Gut Microbiota Contributes to Delirium-Like Behaviors After Abdominal Surgery in Mice. CNS Neurosci. Ther. 25, 685-696. doi: 10.1111/ cns. 13103

Zhan, G., Yang, N., Li, S., Huang, N., Fang, X., Zhang, J., et al. (2018). Abnormal Gut Microbiota Composition Contributes to Cognitive Dysfunction in SAMP8 Mice. Aging (Albany NY) 10, 1257-1267. doi: 10.18632/aging.101464

Zhou, F., Wang, X., Han, B., Tang, X., Liu, R., Ji, Q., et al. (2021). Short-Chain Fatty Acids Contribute to Neuropathic Pain via Regulating Microglia Activation and Polarization. Mol. Pain 17, 1744806921996520. doi: 10.1177/ 1744806921996520

Zhu, S., Liu, S., Li, H., Zhang, Z., Zhang, Q., Chen, L., et al. (2019). Identification of Gut Microbiota and Metabolites Signature in Patients With Irritable Bowel Syndrome. Front. Cell Infect. Microbiol. 9, 346. doi: 10.3389/fcimb.2019.00346

Conflict of Interest: The authors declare that the research was conducted in the absence of any commercial or financial relationships that could be construed as a potential conflict of interest.

Publisher's Note: All claims expressed in this article are solely those of the authors and do not necessarily represent those of their affiliated organizations, or those of the publisher, the editors and the reviewers. Any product that may be evaluated in this article, or claim that may be made by its manufacturer, is not guaranteed or endorsed by the publisher.

Copyright (c) $2021 \mathrm{Xu}$, Chen, Zhan, Wang, Tan and Xu. This is an open-access article distributed under the terms of the Creative Commons Attribution License (CC BY). The use, distribution or reproduction in other forums is permitted, provided the original author(s) and the copyright owner(s) are credited and that the original publication in this journal is cited, in accordance with accepted academic practice. No use, distribution or reproduction is permitted which does not comply with these terms. 